\title{
SISTEMAS DE LAZER E VIOLÊNCIA URBANA: ESTUDO DA RELAÇÃO NO MUNICÍPIO DE PIRACICABA-SP
}

\author{
HELENA BARONE FREIRE
}

Dissertação apresentada à Escola Superior de Agricultura "Luiz de Queiroz", Universidade de São Paulo, para obtenção do título de Mestre em Agronomia, Área de Concentração: Fitotecnia.

P I R A C I C A B A

Estado de São Paulo - Brasil

Fevereiro - 2005 


\section{SISTEMAS DE LAZER E VIOLÊNCIA URBANA: ESTUDO DA RELAÇÃO NO MUNICÍPIO DE PIRACICABA-SP}

\section{HELENA BARONE FREIRE}

Engenheiro Agrônomo

Orientador: Prof ${ }^{a}$. Dr ${ }^{a}$. ANA MARIA LINER PEREIRA LIMA

Dissertação apresentada à Escola Superior de Agricultura "Luiz de Queiroz", Universidade de São Paulo, para obtenção do título de Mestre em Agronomia, Área de Concentração: Fitotecnia.

P I R A C I C A B A

Estado de São Paulo - Brasil

Fevereiro - 2005 
Dados Internacionais de Catalogação na Publicação (CIP) DIVISÃO DE BIBLIOTECA E DOCUMENTAÇÃO - ESALQ/USP

Freire, Helena Barone

Sistemas de lazer e violência urbana: estudo da relação no município de Piracicaba SP / Helena Barone Freire. - - Piracicaba, 2005.

75 p. : il.

Dissertação (Mestrado) - - Escola Superior de Agricultura Luiz de Queiroz, 2005.

Bibliografia.

1. Arborização 2. Espaço livre 3. Espaço urbano 4. Lazer 5. Loteamento 6. Violência urbana I. Título

CDD 715.2

"Permitida a cópia total ou parcial deste documento, desde que citada a fonte - O autor" 
"Cada geração desenha seu perfil e seu entorno:

Cada geração inventa sua identidade e sua circunstância; Cada geração escava seu rosto e sua paisagem.

Somos todos responsáveis pelo olhar que contempla como pelo panorama contemplado".

(Luis Fernández - Galiano) 
Aos meus preciosos pais, dedico.

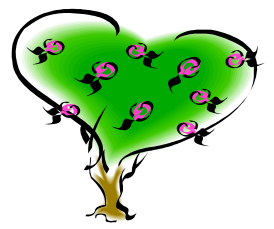




\section{AGRADECIMENTOS}

À minha família, pelo apoio e amor irrestritos.

À minha orientadora, Prof ${ }^{a}$. Dra . Ana Maria Liner Pereira Lima, pela orientação, confiança, amizade e, principalmente, pela possibilidade de fazer escolhas próprias.

À Eliana kämpf e sua preciosa palestra, mola propulsora deste estudo.

Ao Prof. Dr. Marcos Sorrentino, pelo resgate da sensibilidade.

Ao Prof. Dr. Felisberto Cavalheiro, in memoriam, por me mostrar o lado social da paisagem.

À minha irmã Beatriz, pelo estímulo, coragem e competência incontestáveis.

À querida amiga Giuliana Del Nero Velasco, por sua amizade, paciência $e$ precioso apoio.

Ao Yuri Tavares Rocha, por todo o apoio.

Ao Dr. Antonio Geraldo Buck, pelo otimismo, carinho e cuidado com a saúde.

À Dra. Milene Telezzi, Promotora de Justiça da Infância e Juventude da Comarca de Piracicaba, pela indicação das fontes de dados que permitiram a realização desta dissertação.

A toda a equipe do projeto "Acolhimento à criança $e$ ao adolescente em situação de rua", em especial ao seu Coordenador, Robson Leite Gonçalves, e à psicóloga Cristiane Maria Correia, do CRAMI, por toda a atenção despendida, confiança no fornecimento de informações e estímulo para o desenvolvimento deste trabalho. 
Aos membros da entidade Serviço de Apoio ao Menor de Piracicaba (SEAME), por toda paciência e empenho despendidos na coleta de dados, confiança no fornecimento de informações e interesse pela proposta deste estudo.

Ao Sr. Noel, morador do Conjunto Habitacional Bosques do Lenheiro, que me acompanhou na realização do arquivo fotográfico desta pesquisa.

A Lígia Nerina Rocha Duarte e Arlet Maria Almeida, do IPPLAP, por todo o apoio e material fornecido.

Aos companheiros da PPG em Fitotecnia, em especial àqueles da área de paisagismo, como Isabel, Eltiza, Ivan, Henrique, Denise e Vanessa.

Aos integrantes da banca examinadora da qualificação: Prof. Dr. Valdemar Antonio Demétrio, Prof. Dr. João Alexio Scarpare Filho e Prof. Dr. Lindolpho Capellari Júnior.

À Luciane Aparecida Lopes, secretária da PPG em Fitotecnia pela amizade e apoio nos últimos anos.

Ao Prof. Dr. Pedro Jacob Christoffoleti, Coordenador da PPG em Fitotecnia, por todas as orientações e benefícios concedidos durante o Mestrado.

A Deus, pela força para superar limitações. 


\section{SUMÁRIO}

Página

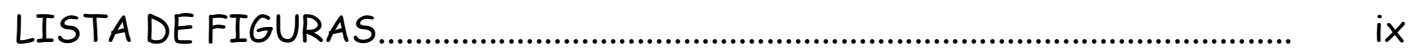

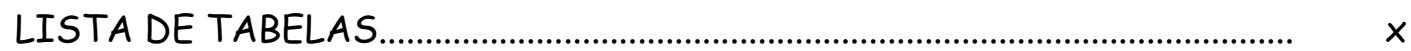

RESUMO

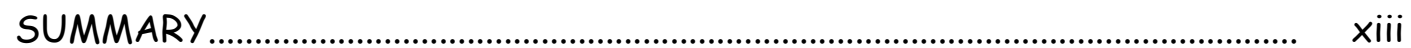

1 INTRODUÇÃ

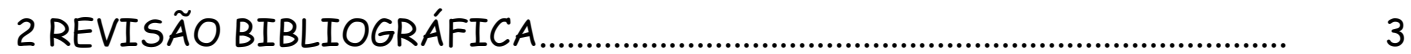

2.1 Caracterização da violência.............................................................................. 3

2.2 Pobreza e desigualdade social............................................................................. 7

2.3 Espaços livres urbanos: importância e influência no comportamento

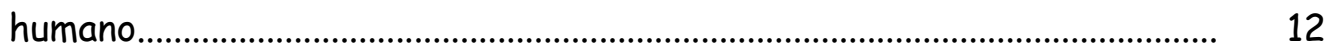

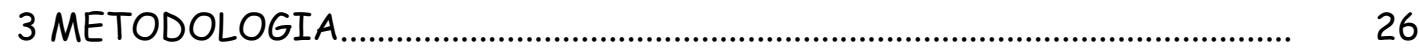

3.1 Dados sobre a violência e a definição da área de estudo.............................. $\quad 27$

3.2 Levantamento de dados sobre os sistemas de lazer da área de estudo... $\quad 31$

4 RESULTADOS E DISCUSSÃO

4.1 A violência no município de Piracicaba-SP...................................................... 32

4.1.1 Dados do projeto "Acolhimento à criança e ao adolescente em situação de rua"

4.1.2 Dados da organização não-governamental Serviço de Apoio ao Menor

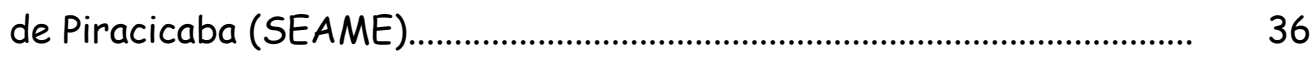

4.2 Conjunto Habitacional Bosques do Lenheiro.................................................... 
4.2.1 Localização e breve histórico........................................................................ 44

4.2.2 Os moradores................................................................................................. 4

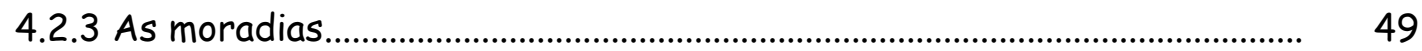

4.2.4 Acesso a equipamentos públicos............................................................... 50

4.2.5 Sistemas de lazer do loteamento................................................................ 52

5 CONCLUSÃO

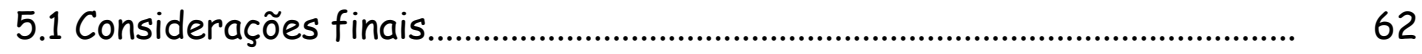

ANEXOS

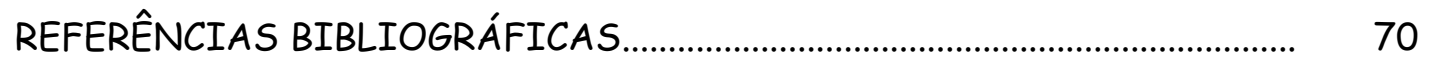




\section{LISTA DE FIGURAS}

Página

1 Faixa etária dos jovens infratores.................................................................. 37

2 Atividade cotidiana dos jovens infratores...................................................... 38

3 Renda familiar dos jovens infratores................................................................ 40

4 Número de pessoas existentes por moradia dos jovens infratores.............. 41

5 Distribuição dos jovens infratores por região do município

de Piracicaba...

6 Localização do Bairro Mário Dedini na Região Norte do município

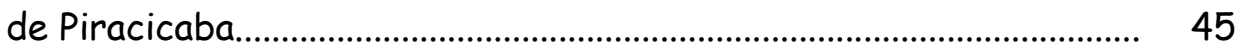

7 A moradia ou "embrião" no Bosques do Lenheiro.............................................. 50

8 Situação atual dos sistemas de lazer do loteamento......................................... 54

9 Situação atual dos sistemas de lazer non-aedificandi do loteamento.......... 56

10 Área de preservação permanente presente entre sistemas de lazer não implantados........................................................................................ 59 


\section{LISTA DE TABELAS}

Página

1 Rendimento dos chefes de família em Piracicaba................................................ 26

2 Faixa etária das crianças e adolescentes em situação de rua......................... 33

3 Escolaridade das crianças e adolescentes em situação de rua......................... 33

4 Infrações cometidas pelos jovens infratores..................................................... 39

5 Procedência dos jovens infratores no município de Piracicaba......................... 42

6 Sistemas de lazer do loteamento Bosques do Lenheiro,

com identificação, metragem e classificação 


\title{
"SISTEMAS DE LAZER E VIOLÊNCIA URBANA: ESTUDO DA RELAÇÃO NO MUNICÍPIO DE PIRACICABA - SP"
}

\author{
Autora: HELENA BARONE FREIRE \\ Orientadora: Prof ${ }^{a}$. Dr ${ }^{a}$. ANA MARIA LINER PEREIRA LIMA
}

\section{RESUMO}

Esta pesquisa traz evidências sobre a relação entre a oferta de sistemas de lazer e a violência urbana, envolvendo crianças e adolescentes, no município de Piracicaba, estado de São Paulo. Em uma primeira etapa, definiu-se uma área de estudo através de dados de procedência de crianças e adolescentes em situação de rua, e de jovens infratores em cumprimento de medidas socioeducativas, dados esses obtidos a partir de duas fontes indicadas pela Promotoria de Justiça da Infância e Juventude da Comarca de Piracicaba (projeto "Acolhimento à criança e ao adolescente em situação de rua" e organização não-governamental Serviço de Apoio ao Menor de Piracicaba - SEAME). Posteriormente, nessa área de estudo, analisou-se a disponibilidade e a situação atual dos sistemas de lazer à população local, e como tal, o Conjunto Habitacional Bosques do Lenheiro foi apontado para a 
realização desta pesquisa, por ser aquele de maior procedência de crianças $e$ adolescentes em situação de rua - 34,5\% do total analisado - e de jovens infratores em cumprimento de medidas socioeducativas - 9,2\% do total analisado. Este loteamento de interesse social caracterizou-se por ser o mais pobre da Região Norte do município, bastante populoso e com alta concentração de jovens, já que a faixa etária de 0 a 20 anos de idade representa quase $55 \%$ da população. Não há sistemas de lazer efetivamente implantados disponíveis aos moradores. Nenhuma das dez áreas públicas destinadas a esse fim recebeu algum tipo de tratamento pela Prefeitura, e estavam todas abandonadas. De maneira geral, a situação da arborização no loteamento mostrou-se crítica: além dos já referidos sistemas de lazer não implantados, as áreas de preservação permanente também não receberam a devida atenção e a arborização de ruas era praticamente inexistente. A revisão bibliográfica realizada neste estudo apontou para uma relação realmente consistente entre arborização, lazer e redução da violência, não só em países do Hemisfério Norte, como no Brasil. Embora a oferta de arborização e lazer representasse apenas uma pequena parcela das carências observadas na área de estudo, a implantação de sistemas de lazer poderia contribuir para que esta se tornasse, ambiental e socialmente, um local melhor para se viver. 
"PUBLIC OPEN SPACES AND URBAN VIOLENCE: STUDY OF ITS RELATIONSHIP IN THE MUNICIPALITY OF PIRACICABA - SP"

Author: HELENA BARONE FREIRE

Adviser: Prof ${ }^{a}$. Dr ${ }^{a}$. ANA MARIA LINER PEREIRA LIMA

\section{SUMMARY}

This research brings evidence of the relationship between the availability of public open spaces and urban violence involving children and teenagers in the municipality of Piracicaba, São Paulo state. To start with, a study area was defined according to two data sources on violence made available by the public prosecutor of the judicial district of Piracicaba (project "Shelter for children and teenagers in street situation" and nongovernmental organization Service Support to the Underage of Piracicaba - SEAME) that showed where the neighborhoods children and teenagers in street situation and young offenders under alternative judicial sentence come from in the municipality. These findings analyzed the availability and actual situation of public open spaces for the population residing in that area. The "Conjunto Habitacional Bosques do Lenheiro" was identified in this research as 
the study area because this is the place most of the children and teenagers in street situation - $34,5 \%$ of the total analyzed - and young offenders under alternative judicial sentence $-9,2 \%$ of the total analyzed - came from. This social interest allotment was characterized as the poorest place in the North region in the municipality, very populated and its residents since the age between 0 to 20 years old represents almost $55 \%$ of the population. It was found that no public open spaces had been made available for the population. The ten areas that the local government was supposed to deal with, were abandoned. In addition, urban forestry in this allotment was very low: beyond those not implanted public open spaces, the planting along the permanent preservation areas had not been implemented and street trees were almost nonexistent. The literature reviewed in this research showed a consistent relationship between urban forestry, leisure and violence reduction in the Northern Hemisphere countries and also in Brazil. The lack of urban forestry and leisure represents a very small part of the privation observed in the study area, but the availability of public open spaces might turn it into an environmentally and socially a more supportive place to live. 


\section{INTRODUÇÃO}

O interesse pelo tema proposto é resultante de indagações tanto pessoais quanto profissionais, que motivaram a busca por referenciais teóricos para verificar ser ou não possível associar campos de pesquisa aparentemente tão distantes num só estudo, mantendo, contudo, o elo fitotécnico de minha formação profissional.

Antes mesmo de meu ingresso no Mestrado, acompanhava um grupo de pessoas que desenvolvia atividades voluntárias com crianças e adolescentes carentes da cidade de Piracicaba-SP, visitando algumas casas nas quais elas encontravam-se agrupadas. A princípio, tomada pela emoção e pela responsabilidade de cumprir meu papel como doadora de atenção e carinho para aqueles meninos $e$ meninas, por muito tempo não questionei, exatamente, quem eram, de onde vinham $e$, inclusive, por que ali estavam.

Com o passar do tempo, as interrogações surgiram e se avolumaram. A cada visita, uma nova e triste história. Dei-me conta de que aquelas casas eram abrigos de acolhimento, e que as crianças haviam sido encontradas nas ruas da cidade ou separadas de suas famílias por ordem judicial, devido a maus-tratos. Diante dessa lamentável constatação, fui tomada por diversos e contrastantes sentimentos, mas, sobretudo, por uma forte necessidade de agir.

$\mathrm{Se}$, por um lado, a realidade desses meninos e meninas me incomodava, por outro, à medida que me envolvia nas discussões e estudos do paisagismo - minha 
área de especialização no Mestrado -, colocava-me frente a frente com a problemática das áreas verdes públicas da cidade, sua ausência, abandono, e cada vez mais sentia a necessidade de contarmos com um planejamento urbano eficiente.

Em meio a tantas discussões acerca dos benefícios do verde urbano, uma palestra a que assisti enfocou, justamente, a relação existente entre espaços comunitários arborizados e a violência urbana, mostrando a possibilidade de, através da implantação efetiva dos primeiros, colaborar para a minimização da segunda. Não estaria aí, talvez, o ponto de interseção daquilo que julgava tão paralelo e que tinha tanto a ver com minha área pretendida de trabalho?

Sob esse enfoque, o presente estudo foi concebido, tendo por principais objetivos:

- Procurar evidenciar, no município de Piracicaba-SP, uma área que concentrasse os maiores índices de violência, verificando, também, a disponibilidade de sistemas de lazer à população dessa área;

- Analisar a situação atual dos sistemas de lazer encontrados;

- Levantar, em literatura, fontes que estabeleçam relação entre lazer, arborização e violência, buscando justificar propostas de melhoria na qualidade de vida dessas populações, pelo menos contemplando-as com áreas onde, além da função ecológica e estética, oportunidades de lazer devam ser efetivadas. 


\section{REVISÃO BIBLIOGRÁFICA}

\subsection{Caracterização da violência}

Como sugere Waiselfisz (1998), não é fácil definir violência, pois é um termo que denomina uma série de situações sociais que foram se transformando no tempo, no espaço e de um período histórico para outro. Em sentido estrito, segundo Silveira (2000), entende-se violência como a intervenção física de um indivíduo ou grupo contra a integridade de outro(s) grupo(s) e também contra si mesmo, abrangendo desde os suicídios, espancamentos de vários tipos, roubos, assaltos e homicídios até a violência no trânsito, disfarçada sob a denominação de acidentes, $e$ todas as diversas formas de agressão sexual.

Waiselfisz (2000), ressalta que houve um alargamento do entendimento da violência nas últimas décadas, em função das transformações na natureza das relações sociais e nas percepções sobre os direitos humanos, ampliando-se o conceito e incluindo eventos que passavam por práticas costumeiras nas relações sociais, como a violência intrafamiliar, contra a mulher ou as crianças, a violência simbólica contra grupos, categorias sociais ou etnias, entre outros. A violência não é apenas física; engloba, também, situações de humilhação, exclusão, ameaças, desrespeito, indiferença, omissão com relação ao outro. Waiselfisz (2000, p.9), enfatiza que hoje ela "se encontra ligada ao conceito de alteridade, nas formas e mecanismos pelos quais a sociedade convive com as diferenças". 
De maneira concisa, Santana \& Carvalho Ferriani (2001, p.96) consideram a violência "[...] um fenômeno multicausal que vem atingindo, indistintamente, todos os grupos sociais, instituições e faixas etárias, na qual os indivíduos ora se apresentam como vítimas, ora como agressores". Devido às proporções que vem assumindo no ambiente urbano, tornou-se alvo de estudos e preocupação de profissionais $e$ segmentos da sociedade, não apenas como decorrência do clima de insegurança gerado em todas as esferas sociais, mas pelo custo que vem representando a todos.

Um dos temas mais discutidos é a grande incidência de casos envolvendo crianças e adolescentes, como vítimas ou como agressores, nas várias manifestações de violência. Embora algumas pesquisas tratem da questão dos jovens de classe média, a maior parte da bibliografia está centrada em jovens das periferias dos grandes centros urbanos. Enfatizam-se aspectos da exclusão do mercado de trabalho e dos serviços de bens de consumo urbanos, destacando o seu envolvimento com os tráficos de drogas e de armas, o que resulta, muitas vezes, na morte precoce de tantos (Waiselfisz, 1998).

De acordo com Adorno (1999), desde o início dos anos 1970, a presença de crianças e adolescentes em situação de rua, nas grandes cidades brasileiras, "guardando" carros estacionados ou vendendo balas no trânsito por pequena quantia de dinheiro, era considerada um problema social, e, com o rápido aumento dos crimes violentos $^{1}$ nas cidades, passou-se a temer um maior $e$ inexorável envolvimento desses jovens no mundo do crime, especialmente aqueles das classes trabalhadoras mais pobres.

A partir dos anos 1980, a sociedade vivenciou uma explosão dos crimes violentos nos grandes centros urbanos. Como demonstra Caldeira (2000), na região

\footnotetext{
${ }^{1}$ A categoria "crimes violentos" engloba as formas mais violentas de delito: homicídios, tentativas de homicídios, lesão corporal dolosa, estupro, tentativa de estupro, roubo $e$ latrocínio (Caldeira, 2000).
} 
metropolitana de São Paulo, representavam, no início daquela década, cerca de $20 \%$ do total de crimes registrados; depois de 1984, passaram a representar cerca de $30 \%$ do total, chegando a $36,28 \%$, em 1996. Tal crescimento foi maior nos municípios que compõem a região metropolitana de São Paulo (cerca de 5\% ao ano) do que na capital do estado ( $4,22 \%$ ao ano), evidenciando que a violência urbana não se faz igualmente presente em todas as áreas das grandes cidades, sendo as mais violentas aquelas que, do ponto de vista físico, caracterizam-se por terem pouca infra-estrutura (Cardia, 1998; Santos, 2002).

A violência tem suas vítimas preferenciais: crianças $e$ adolescentes moradores de periferias e favelas urbanas, cuja idade varia de 15 a 25 anos (Santos, 2002). Vem ocorrendo, principalmente, com homens jovens das grandes cidades, mas afeta também jovens moradores de cidades do interior, sendo o homicídio ${ }^{2}$ a primeira causa de mortalidade dessa faixa etária (Cardia, 1998).

Além de vítimas preferenciais, estes jovens são também agentes dessa violência. Santos (2002, p.3), aponta o perfil dos infratores: "[...] jovens recrutados entre grupos de trabalhadores de baixa renda, desempregados ou subempregados no mercado informal de trabalho, na faixa etária dos 16-17 anos [...]". Adorno (1999), ressalta que a juventude não é mais ou menos violenta que a população como um todo, mas há fortes evidências de que recentes mudanças no consumo e tráfico de drogas tenha alterado rapidamente o seu padrão de comportamento, resultando no aumento dos crimes violentos praticados.

\footnotetext{
${ }^{2} \mathrm{O}$ indicador geral de violência na sociedade tem sido o registro de mortes por violência de acordo com Waiselfisz (2000, p.12) "nem toda, sequer a grande maioria das violências cotidianas terminam em morte; mas a morte representa o grau extremo da violência". Segundo o autor, não existem muitas outras alternativas: o registro de queixas à polícia sobre diversas formas de violência tem uma abrangência extremamente limitada; já no campo dos óbitos, é possível contar com um Sistema de Informações sobre Mortalidade que, além de centralizar informações sobre todo o país, cobre um universo bem significativo das mortes ocorridas e de suas causas.
} 
Por trás do crescente envolvimento da criança e do adolescente no mundo do crime, há o problema da violência doméstica (ou intrafamiliar) ${ }^{3}$ que, segundo Castro et al. (2001), é tida por muitos como o elemento desencadeador do que poderia ser denominado cadeia de violências - "pais e mães violentos que têm os filhos como suas vítimas que, por sua vez, se tornariam violentos fazendo outras vítimas" (Castro et al., 2001, p.75). Embora seja vivenciada em todas as classes sociais, é nas classes populares que a violência ganha maior visibilidade, pois são as que mais procuram os serviços públicos (Deslandes, 1994).

Uma das principais causas da ida de crianças e adolescentes para as ruas é a condição socioeconômica. Muitas famílias em situação de pobreza encontram como alternativa permitir que seus filhos pratiquem a mendicância ou outras atividades, tais como "guardar" carro e vender diversos objetos, inclusive estimulando-os (CRAMI, 2002: Piracicaba, 2002a). A deterioração dos laços familiares e a violência doméstica - têm sido identificados como fatores desencadeantes aspectos como estresse, desemprego, baixos salários, filhos não desejados, falta de condições de sobrevivência, uso de drogas e alcoolismo (Deslandes, 1994) seriam outras causas que os impulsionariam (Castro et al., 2001; CRAMI, 2002; Piracicaba, 2002a). Nas ruas, vulneráveis a todos os perigos que estas oferecem, adentram precocemente ao mundo do vício (drogas, prostituição) e do crime em seus diferentes níveis (CRAMI, 2002).

Castro et al. (2001) vêem a ausência de equipamentos e atividades de lazer disponíveis para a ocupação do tempo livre dos jovens, nas comunidades que residem, como uma lacuna que pode ser explorada pelo tráfico de drogas, pois

\footnotetext{
3 Pode se manifestar através de quatro tipos principais: física, sexual, psicológica e negligência/abandono (Deslandes, 1994).
} 
"[...] no ambiente de exclusão social a que estão submetidas as comunidades onde vivem os jovens, a atividade no tráfico é uma via de satisfação de aspirações de consumo para a qual a sociedade não oferece meios legítimos" (Castro et al., 2001, p.84).

O aumento da violência, a taxas nunca vividas pelas metrópoles é um dos indicadores mais expressivos e definitivos da piora das condições de vida urbana, afirma Maricato (2001), para quem é impossível dissociar o território das condições socioeconômicas e da violência:

"concentração territorial homogeneamente pobre (ou segregação espacial), ociosidade e ausência de atividades culturais $e$ esportivas, ausência de regulação social e ambiental, precariedade urbanística, mobilidade restrita ao bairro, e, além dessas características todas, o desemprego crescente que, entre outras consequiências, tende a desorganizar núcleos familiares $e$ enfraquecer a autoridade dos pais, essa é a fórmula das bombas socioecológicas" (Maricato, 2001, p.36).

A preocupação em se combater a violência contra crianças e adolescentes deve-se ao fato de que esta

"[...] compromete o seu crescimento e desenvolvimento, deixando seqüelas duradouras e a matriz para que o círculo da violência se reproduza contra outras crianças e adolescentes do futuro, pois assim se aprende, na prática, como maltratar" (Santana \& Carvalho Ferriani, 2001, p.99).

\subsection{Pobreza e desigualdade social}

A qualidade ambiental e a qualidade de vida, nas grandes cidades, têm sido alteradas em função de problemas gerados pela falta de organização na ocupação do meio urbano. Segundo Silva (2002), de forma desordenada, sem critérios e sob olhar, muitas vezes, distante do poder público, a cidade cresce, colocando em risco 
não apenas os recursos naturais existentes, como também impõe limites às outras necessidades humanas, como espaço para morar, para o lazer, para a convivência na sociedade.

"[...] não se tem qualidade de vida sem qualidade ambiental. A população necessita de condições sócio-estruturais como emprego, habitação, escola, lazer e soma-se a essas necessidades, um quadro minimamente equilibrado, área verde, córregos e atmosfera não poluídos" (Silva, 2002, p.66).

Já na Carta de Atenas (Le Corbusier, 1989), propôs-se que as cidades deveriam se organizar de forma a satisfazer quatro necessidades básicas dos seres humanos: habitar, trabalhar, recrear e circular; consideradas as chaves do urbanismo. No entanto, o planejamento preventivo e democrático representa, até os dias atuais, um grande desafio para técnicos, administradores e planejadores.

A literatura especializada desvincula a violência da pobreza e aponta a relação entre desigualdade social (traduzida pelo restrito acesso aos direitos sociais) e violência como a relação mais provável (Castro et al., 2001; Maricato, 2001 e Santos, 2002).

De acordo com Santos (2002), se há dúvidas sobre a relação entre pobreza e violência, é possível afirmar que há uma coincidência entre algumas características das comunidades mais afetadas pela violência nos grandes centros urbanos: "[...] são regiões com maior nível de pobreza, de ocupação recente $e$ desordenada, que pouca atenção recebem das autoridades públicas [...]" (Santos, 2002, p.2). São as favelas e as periferias caracterizadas pela precariedade da infra-estrutura e pela baixa qualidade de vida coletiva (Cárdia, 1998; Castro et al., 2001; Maricato, 2001 e Santos, 2002).

A periferia é caracterizada por Santos (2002) como os locais mais distantes das regiões centrais, na maioria das vezes com déficit de infra-estrutura e excesso 
populacional. São áreas geralmente desvalorizadas devido às dificuldades que seus moradores encontram no local, tais como distância das regiões centrais e escassez de transportes, falta de água canalizada, rede de esgotos e iluminação pública, além dos interesses imobiliários. Embora alguns loteamentos sejam regulares, muitas vezes os loteadores não cumprem uma série de obrigações legais (como o fornecimento prévio de água, luz e rede de esgoto), tornando-os irregulares. Além destes, existem os loteamentos clandestinos e as invasões (geralmente sobre terrenos públicos), ambos marcados pelo desmatamento quase total, ocupação em áreas de risco, autoconstrução, esgotos a céu aberto, ligações clandestinas de água e luz, entre outras características.

De acordo com Nucci (1996), a alta densidade populacional está diretamente relacionada a características como desconforto, riscos de doenças, deficiência no abastecimento em geral, problemas na eliminação e deposição de lixo, mal-estar, ruídos, poluição, falta de privacidade, competição, congestionamento nas ruas, escassez de espaços livres para o lazer, falta de participação popular; em resumo, deterioração da qualidade de vida urbana.

Segundo De Angelis (2000), o processo de deterioração do padrão urbanístico é uma característica da urbanização brasileira recente, através da qual o crescimento urbano vem acompanhado do distanciamento das populações de baixa renda para periferias, em áreas mal dotadas de serviços e de baixo padrão urbanístico. Se, por um lado, o rápido crescimento de uma cidade, na ausência de planejamento, propicia o surgimento de áreas carentes em infra-estrutura básica, "[...] o que dizer então de estruturas vistas como menos importantes - praças, arborização urbana e parques?" (De Angelis, 2000, p.27). A esse respeito, para Müller (2002), os espaços e equipamentos de lazer não recebem a atenção necessária por parte das políticas públicas porque ainda não são valorizados nem entendidos como essenciais. O mesmo pode ser dito sobre a arborização; 0 
desconhecimento do seu potencial como propiciadora de benefícios ao ambiente e à população faz com que seja considerada supérflua.

De acordo com Castro et al. (2001), estudos da Organização das Nações Unidas para a Educação, Ciência e a Cultura (UNESCO) verificaram haver um fato comum sobre o cotidiano de jovens que vivem em bairros de setores populares no Brasil: o caráter rotineiro de suas vidas, inclusive quanto às atividades de lazer, quer por carência de equipamentos em suas comunidades quer por dificuldades de acesso aos equipamentos concentrados em bairros de classe média e alta, inclusive por não possuírem meios econômicos que lhes garantam o uso de bens culturais urbanos, mesmo em se tratando de atividades realizadas em áreas públicas. Neste particular, Cardia (1998, p. 136) ilustra a situação dos bairros mais violentos de São Paulo:

"[...] faltam áreas de lazer. Os espaços coletivos, quando existem, não são seguros ou mantidos em condições de uso: mães não dispõem de um local para as crianças tomarem sol ou brincarem; crianças e adolescentes não têm espaço para brincarem ou praticarem esportes. Não dispõem, assim, de locais para desenvolverem regras de competição e de cooperação. $O$ meio ambiente não permite prazer estético, ou seja, os espaços coletivos, além de insuficientes, são tão desagradáveis que agudizam o estresse. Impossibilitam um lazer saudável e também possuem uma carga simbólica: são ambientes desvalorizados, carregados de conotação - simbolizam a desvalorização que se atribui a seus moradores. [...] são de aparência árida - sem áreas verdes e vegetação [...] de características pouco atraentes para quem nele mora e trabalha".

É justamente nessas regiões das cidades que a ação do poder público é decisiva, porque os espaços livres públicos, que deveriam estar ao alcance de toda a população, não são distribuídos democraticamente na malha urbana, estando concentrados em regiões relativamente ricas ou, ainda, em bairros privilegiados, 
acompanhando a especulação imobiliária, onde as pessoas têm acesso, inclusive, a opções de lazer de caráter privado.

Nesse sentido, Marcellino ${ }^{4}$, citado por Silveira (2000), afirma que o acelerado crescimento das nossas cidades provocou uma série de descompassos. $O$ aumento da população urbana não foi acompanhado pelo desenvolvimento da infraestrutura, gerando desníveis na ocupação do solo e diferenciando marcadamente, de um lado, as áreas centrais, concentradoras de benefícios, e, de outro, a periferia, um verdadeiro depósito de habitações. Tal situação é agravada se considerarmos que, cada vez mais, as camadas menos favorecidas da população vêm sendo expulsas para a periferia e, portanto, afastadas dos serviços, dos equipamentos específicos; são justamente as pessoas que não podem contar com as mínimas condições para a prática do lazer em suas residências, e para quem o transporte adicional, além de economicamente inviável, é desgastante.

Esse descompasso não ocorre apenas nos grandes centros urbanos. Geraldo (1997), analisando as praças, parques e jardins públicos das cidades de Bariri, Brotas e Dois Córregos, localizadas no interior do estado de São Paulo, verificou que nem todos esses espaços públicos relacionados pelas prefeituras estavam efetivamente implantados, existindo, apenas, a área física, sem equipamentos ou vegetação. Para alguns, havia projetos elaborados; para outros, nem isso. De acordo com o autor, em geral, estes espaços estavam localizados nas regiões de expansão mais recente ou em conjuntos habitacionais, justamente nos quais se faz mais urgente a sua implantação, uma vez que esses locais são mais afastados das áreas centrais, melhor providas de verde e atividades de lazer.

Muitos outros exemplos referentes a essa tamanha desigualdade constatada nas cidades brasileiras poderiam ser mencionados individualmente, pois são

\footnotetext{
${ }^{4}$ MARCELLINO, N.C. O lazer e a cidade: uma questão urbana. In: Congresso da Cidade construindo a cidade do futuro, 3., Porto Alegre, 2000. Anais. Porto Alegre, 2000.
} 
diversas as pesquisas realizadas nesse âmbito. Entretanto, como fazem referência Castro et al. (2001), a publicação da "Pesquisa de Informações Básicas Municipais 1999", pelo IBGE, proporciona uma visão geral do estado dos equipamentos culturais e sociais nos municípios brasileiros, cujos indicadores justificam e reforçam a preocupação com a falta de espaços de lazer e cultura para a população jovem, em especial para aqueles em situações de pobreza. Ressaltam, ainda, que, nos municípios que são capitais de estados de grande porte, a razão entre equipamentos e população jovem deixa a desejar.

É importante destacar que, como refere Santos (2002) ao analisar o caso da região metropolitana de São Paulo, a desigualdade no acesso aos direitos sociais - $e$ o direito a cultura, ao esporte e ao lazer é apenas parte destes - somada à pobreza da população, parece aumentar os riscos de tais áreas serem contextos preferenciais de crimes violentos. "Mais do que garantir o acesso ao esporte, a cultura e ao lazer, o poder público deve garantir os serviços públicos essenciais à população e cuidar para que este atendimento seja de qualidade" (Santos, 2002, p. 38).

O espaço público é o espaço da cidade, de todo cidadão e da vida comunitária, por excelência. Paiva \& Gonçalves (2002), ressaltam que a distribuição inadequada ou a simples inexistência de áreas verdes públicas, em cada município, pode ser considerado um problema social à medida que priva das opções de lazer e de recreação, assim como da melhoria da qualidade do ambiente.

\subsection{Espaços livres urbanos: importância e influência no comportamento humano}

Parece não haver dúvida de que uma das maiores dificuldades enfrentadas por profissionais engajados no ensino e pesquisa, como no planejamento e gestão do verde urbano, é a divergência na conceituação e utilização dos termos técnicos. 
A ausência de linguagem única dificulta sobremaneira a identificação, classificação e quantificação do verde, refletindo-se diretamente no seu conhecimento, valorização e, em última instância, no desenvolvimento de pesquisas cujo intuito seja auxiliar a formulação de políticas públicas com vistas a garantir qualidade de vida em nossas cidades.

Lima et al. (1994), tendo em vista a problemática, estabeleceram uma proposta de conceituação dos termos técnicos mais comumente utilizados, tornando-se referência para o desenvolvimento de estudos posteriores. Dentre as suas proposições, temos:

Espaço livre é o conceito mais abrangente; integra os demais e contrapõe-se ao espaço construído em áreas urbanas. Deve satisfazer três objetivos principais: ecológico, estético e de lazer:

Arborização urbana refere-se aos elementos vegetais de porte arbóreo dentro da cidade. Sob este ponto de vista, as árvores plantadas em calçadas fazem parte da arborização urbana; entretanto, não integram o sistema de áreas verdes.

Diante da persistência da grande confusão quanto aos termos, Cavalheiro et al. (1999) propõem que antes de discuti-los é preciso, primeiramente, entender que a legislação brasileira estabelece que o município está dividido em zona urbana, de expansão urbana e zona rural. Embora não seja explicitamente mencionada, a zona urbana é constituída por: sistema de espaços com construções (habitação, indústria, comércio, hospitais, escolas, entre outros), sistema de espaços livres de construção (praças, parques, águas superficiais, entre outros) e sistema de espaços de integração urbana (rede rodo-ferroviária). Assim, propõem: 
"Espaços livres de construção constituem-se de espaços urbanos ao ar livre, destinados a todo tipo de utilização que se relacione com caminhadas, descanso, passeios, práticas de esportes $e$, em geral, a recreação e entretenimento em horas de ócio; os locais de passeio a pé devem oferecer segurança e comodidade com separação total da calçada em relação aos veículos; os caminhos devem ser agradáveis, variados e pitorescos; os locais onde as pessoas se locomovem por meios motorizados não devem ser considerados como espaços livres. Os espaços livres podem ser privados, potencialmente coletivos ou públicos $e$ podem desempenhar, principalmente, funções estética, de lazer $e$ ecológico-ambientais, entre outras" (Cavalheiro et al., 1999, p.7).

Senna $(2001)^{5}$, reconhece a necessidade de padronização de conceitos, sugerindo a utilização do termo áreas verdes urbanas para designar o conjunto composto por três segmentos individualizados que, para a autora, estabelecem interfaces notáveis entre si: áreas verdes públicas, compostas pelo rol de logradouros públicos destinados ao lazer e recreação ou que oportunizem ocasiões de encontro e convívio direto com espaços não construídos e arborizados; áreas verdes privadas, compostas por remanescentes vegetais significativos incorporados aos interstícios da malha urbana, podendo ter sua utilização normatizada por legislação específica que possa garantir, ao máximo, sua conservação; e arborização de ruas e vias públicas. De acordo com a autora, esse conceito é o mais aceito a nível nacional e internacional, pois, em seu somatório, são capazes de traduzir amplos benefícios às condições ambientais das cidades e à qualidade de vida da população.

5 SENNA, D.C. Proyecto informacion y analisis para el manejo florestal sostenible: integrando esfuerzos nacionales e internacionales en 13 paises tropicales en America Latina: arboles fuera del bosque. País: Brasil. Brasília, 2001. Brasília: FAO, 2001. Material obtido através de comunicação pessoal com membros do Instituto de Pesquisas e Planejamento de Piracicaba, Prefeitura do Município de Piracicaba. 
A Prefeitura do Município de Piracicaba define sistema de lazer ou sistema de recreio a área resultante de parcelamento do solo, reservada ao uso público, destinada a praças, parques, jardins e atividades de recreação e lazer. Da área global de cada empreendimento $10 \%$ (dez por cento), no mínimo, deve ser destinado aos sistemas de lazer ou recreio, porcentual que pode ser ampliado em função da declividade média apresentada pelas áreas reservadas a esse fim (Piracicaba, 1985).

Pelas muitas funções que desempenham, beneficiando o ambiente das cidades e, conseqüentemente, a sua população, para Guzzo (1999, p.8), "[...] a existência desses espaços traduz obrigatoriamente o sentido de qualidade ambiental e de vida em uma cidade". O autor discorre mais profundamente sobre as funções ecológica, estética e social dos espaços livres: contribuem, ecologicamente, na medida em que os elementos naturais que os compõem minimizam os impactos ambientais legados do processo de urbanização $e$ industrialização, no abatimento de ruídos, na melhoria do microclima, na purificação e refrigeração do ar, no abrigo à fauna, entre outros; a contribuição estética refere-se, principalmente, ao papel integrador que exercem entre os espaços construídos e aqueles de circulação. A contribuição social, por sua vez, está diretamente relacionada à oferta de espaços que propiciam o lazer da população, dentre os quais os de caráter público são os mais importantes por possibilitarem o acesso, sem restrições, a qualquer pessoa.

Embora seja difícil encontrar nas cidades espaços livres que cumpram ao mesmo tempo as funções ecológica, estética e social, uma maneira de viabilizá-las seria o fato de esses espaços não estarem totalmente desvinculados da vegetação, principalmente em cidades onde o verde é escasso, assevera Nucci (1996).

Há, ainda, outra função desses espaços, não muito explorada cultural e cientificamente em nosso país, porém não menos importante, como a utilização para fins de produção agrícola e hortifrutícola. Segundo Cavalheiro (1982), por muitos 
anos ouviu-se falar das experiências européia e norte-americana de utilizar espaços livres públicos para hortas comunitárias. Além de colaborar no combate à carência alimentar, tais iniciativas vinculavam uma população com um espaço livre $e$ dinamizavam seu uso.

A rapidez com que se processa a expansão urbana dificulta a execução de planejamentos adequados de ocupação do solo, produzindo-se densos e amplos aglomerados humanos. Com eles, o surgimento de problemas como habitação inadequada, falha na preservação de espaços livres, não-fornecimento de equipamentos e serviços públicos de qualidade e para todos, toda sorte de poluições, acúmulo de construções, agitação e ruídos causados pelo tráfego, tecnologias que introduzem velocidade e mudança de ritmos de vida, resultando em considerável desgaste das energias física e psicológica despedidas pelo homem urbano, na vida cotidiana.

Esses seriam, sem dúvida alguma, fortes argumentos contra as cidades, se em sua própria estruturação não houvesse meios para a reparação de tão graves aspectos adversos, adverte Senna (2001), para quem, de forma alguma e sob qualquer pretexto, o ambiente urbano pode prescindir das áreas verdes urbanas. Para efeito de planejamento, o estudo do potencial dessas áreas deve ser realizado sob o tríplice ponto de vista: da qualidade, da quantidade e da distribuição, levandose em conta, também, a questão da multi e interdisciplinaridade, ressalta a autora.

Corroborando com essa assertiva, se outrora a arborização das cidades era analisada apenas como instrumento embelezador, hoje em dia, principalmente para os técnicos, passou a ser compreendida como elemento fundamental $e$ extremamente útil quanto ao fornecimento de importantes benefícios, segundo Lima (1993).

O papel da arborização, ou da vegetação como um todo, na mitigação de impactos ambientais resultantes do intenso desenvolvimento urbano é bem 
estabelecido, seja pela moderação climática, conservação de energia, redução de gás carbônico, melhoria da qualidade do ar e da água, controle do escorrimento superficial e inundação, entre outros, funcionando a vegetação como antídoto para muitos dos problemas físicos das cidades (Kuo et al., 1998a).

As transformações urbanas também afetaram profundamente a sociedade $e$, para Naftalin ${ }^{6}$, citado por Heimstra \& McFarling (1978, p. 94), o seu impacto social

"[...] não se resume somente numa questão de pobreza, embora este seja certamente seu elemento mais crítico. Envolve uma estrutura mutante de valores que está alterando profundamente a natureza da vida em família e o padrão geral de relacionamento humano. Envolve também um aumento alarmante do uso de álcool e drogas e tensões cada vez maiores que derivam da crescente insegurança e de nossa incapacidade em controlar ou nos pôr a salvo das hostilidades. Envolve um enfraquecimento geral de nossas instituições principais de controle social, especialmente a família e a educação".

Atualmente, as pesquisas buscam o potencial da vegetação na mitigação desses referidos impactos sociais, legados do processo de urbanização.

Já dizia Medeiros, em 1975, ser necessário prever um bom aproveitamento da terra, de modo que os homens não tenham somente boas condições de moradia, mas possam viver nos grandes aglomerados urbanos sem perder o contato com a natureza. Na sua opinião, a recreação de uma comunidade deveria contar, no mínimo, com as seguintes unidades: parques infantis, locais onde os jovens encontrem possibilidades de praticar os seus jogos e esportes prediletos; lugares adequados para reuniões de adultos; acomodações para a família se divertir, como praças e jardins; e áreas de proteção da natureza.

\footnotetext{
${ }^{6}$ NAFTALIN, A. The urban problem and action research. In: KORTEN, F.F.; COOK, S.W.; LACEY, J.I. (Eds.). Psychology and the problems of society. Washington D.C.: American Psycologycal Association, 1970.
} 
Para Nucci (1996), o lazer abrange uma gama de possibilidades, tais como repousar, comer, fazer visitas, cinema, estádio, rádio, televisão, jornal, esportes, jardinagem, fotografia, música, entre outras; e a recreação é uma forma de transformar os momentos de folga para não se deixar cair no ócio. Sob esse ponto de vista,

"[...] o sistema de espaços livres públicos tem, portanto, uma grande parcela de responsabilidade em fornecer opções para que a população encontre, nos momentos de lazer, muitas possibilidades de escolha para a sua recreação ao ar livre [...]" (Nucci, 1996, p. 51).

É importante que haja uma homogênea distribuição espacial dos espaços livres públicos na malha urbana, para acesso dos moradores de todos os bairros, independentemente da classe de renda. Bairros que possuem espaços dotados de boa infra-estrutura e atividades de lazer evitam que usuários precisem se deslocar de uma região para outra da cidade em busca de lazer gratuito, sendo desnecessários gastos adicionais de transporte e tempo pessoal (Carvalho, 2001).

Além do oferecimento de atividades de lazer, é imprescindivel prever um bom plano de manutenção e conservação dos espaços públicos. De acordo com Silveira (2000), os parques, alvos de delitos praticados por delinqüentes, são espaços carentes de atividades e, por estarem degradados, conduzem a práticas anti-sociais que levam à sua própria autodestruição.

Em sua pesquisa de Mestrado, a autora evidenciou indicadores de uma relação inversa entre variáveis de lazer (oferta de espaços livres públicos, sua manutenção e existência de programas socioculturais) e a violência urbana (avaliada pela ocorrência de registro policial de uso, porte e tráfico de tóxicos por jovens) em três Regiões Administrativas do Distrito Federal, onde residem famílias de classe média. Na pesquisa, a variável referente a programas de cunho sociocultural 
não teve uma representatividade tão grande quanto poderia ter em uma localidade de menor poder aquisitivo, visto que a maior parte da população estudada pode utilizar os parques com atividades diferentes daquelas realizadas pela população de menor renda.

Tal observação tem fundamento. Um mapeamento da cidade de São Paulo, promovido pela Organização Mundial de Saúde, com o intuito de avaliar a vulnerabilidade às drogas dos jovens que residem em áreas periféricas, chamou a atenção para a coexistência territorial entre falta de equipamentos de lazer e cultura e altos índices de violência. Nesse estudo, defende-se recorrer a atividades de lazer, cultura e esportes para inibir o uso de energias e tempo gastos em violências e no uso de drogas (Cardia \& Shiffer, 2000).

Ainda a esse respeito, estudos da UNESCO constataram que a violência juvenil no Brasil oscila durante a semana e aumenta nos finais de semana, sendo a arte, a cultura, a educação para a cidadania, o esporte e o lazer apontados como elementos estratégicos para enfrentar e combater a violência (Castro et al., 2001).

Nos mesmos estudos, verificou-se que os jovens das camadas mais populares têm menos acesso aos equipamentos coletivos culturais, esportivos e de lazer, justificando a abertura de escolas às comunidades nos finais de semana, nas quais, além de agregar e maximizar recursos culturais, quer da sociedade quer da comunidade próxima, atendendo à demanda expressa pelos jovens quanto a atividades, são explorados temas relevantes para o seu bem-estar, conjugando ética e estética, prazer, reflexão e criatividade (Castro et al., 2001). 
Esse programa ${ }^{7}$ da UNESCO vem sendo adotado pelo poder público em todo - Brasil em função dos impactos positivos na vida dos jovens, contribuindo para a criação de espaços alternativos, afastando-os das situações, comportamentos $e$ idéias de violência.

$O$ envolvimento de crianças e adolescentes em atividades de lazer pode impedir o desenvolvimento de comportamentos anti-sociais (ao estruturar o seu tempo e lhes impor disciplina), promovendo bem-estar físico e emocional, além de favorecer a integração entre os jovens, e destes com os adultos, criando formas de controle social informal (Santos, 2002). Vê-se que, além das funções de diversão e de descanso, ou recuperação das energias gastas nas atividades cotidianas, as atividades de lazer têm a importante função do desenvolvimento pessoal e social (Müller, 2002).

Adorno (1998, p.13), enfatiza que "o espaço degradado influencia na degradação do cotidiano $e$ dos estilos de vida, o que comprova a relação de reciprocidade entre a vida social e o ambiente". Nos bairros periféricos, a falta de opções de lazer, ou mesmo de praças e áreas verdes, marca sua condição de área insegura, onde a ausência de controle da circulação de armas e do tráfico de drogas gera uma sociabilidade vinculada à violência do extermínio e do auto-extermínio. Para o autor, além da necessidade de se criarem espaços de lazer e locais para o esporte, que fazem parte da "revitalização" da periferia da cidade, é preciso

\footnotetext{
${ }^{7}$ Como esse programa, existem muitas outras experiências desenvolvidas por organizações não-governamentais e entidades do setor público, no sentido de contrapor cultura a violências, desarmá-las ao acionar a auto-estima, promover a participação, a solidariedade $e$ analisar seu impacto na vida dos jovens em situação de pobreza, seus familiares e de suas comunidades. Como objetivo de socializar suas metodologias e práticas, além de oferecer subsídios para políticas públicas, tendo por foco a juventude, Castro et al. (2001) publicaram um livro, apresentando trinta experiências consideradas inovadoras pela UNESCO, já que se afastam da lógica repressiva e dão voz aos jovens.
} 
promover formas de pertencimento (a um local, a uma história, aos laços sociais), possibilitando o fortalecimento da afetividade e identidade.

A esse respeito, Müller (2002) ressalta a riqueza das organizações comunitárias, como produto da cultura popular local, construídas com base na sociabilização e no relacionamento entre vizinhos, entre integrantes da mesma instituição e do mesmo espaço geográfico. À medida que se organizam e buscam autonomia no que diz respeito a decidir o que é melhor para si, ocupam os espaços urbanos de forma democrática e promovem a integração entre as pessoas, com momentos lúdicos, até como forma de expulsar a violência e as condições precárias e de injustiça existentes na comunidade.

"Quando as pessoas se encontram muita coisa boa pode acontecer, quando se isolam dentro de casa o que pode acontecer? Outros, com diferentes interesses, dominam os espaços e equipamentos urbanos. O lazer pode transformar ou ser revolucionário, isto é, a comunhão que desperta entre as pessoas pode vir a produzir transformação" (Müller, 2002, p.14).

Muitas vezes, pelo custo que representam ao poder público, os espaços livres nem chegam a ser implantados. Segundo Presotto (2002), esses espaços sem utilização são vistos como problemas, pois acumulam lixo, dejetos de construção, trazendo, muitas vezes, como consequiência animais indesejados que podem, por exemplo, transmitir doenças à população residente no entorno. Situações desse tipo são lamentáveis, pois, como refere Presotto (2002, compact disc), embora não se conheçam todos os benefícios que os espaços livres exercem sobre a cidade ou no cotidiano das populações que os utilizam, "[...] sabe-se que, nos locais onde implantados, são de imediato utilizados pela população local [...]".

Deve-se levar em conta que, por mais que não seja possível incluir em seu projeto uma variedade de equipamentos de lazer, é muito importante que o espaço 
livre exista e tenha, pelo menos, a potencialidade ecológica, como afirma Nucci (1996), deixando para a comunidade o direito de usufruí-lo da maneira que desejar. Tão embora as pessoas tenham dificuldade em reconhecer o papel ambiental desempenhado pelo verde urbano, elas se sentem agraciadas ao caminhar sob árvores, usufruir sua sombra, caminhar sobre gramados, observar plantas em florescimento, admirar o canto dos pássaros.

Segundo pesquisas realizadas na região central $^{8}$ da cidade de Chicago (EUA), habitada por população de baixa renda, espaços comunitários atraentes e bem utilizados podem proporcionar importantes benefícios à comunidade. Verificou-se que, quanto mais providos de vegetação (árvores e grama), mais atraíram as pessoas ao ar livre, aumentando a oportunidade de encontros sociais informais entre os vizinhos e promovendo o desenvolvimento de laços sociais de vizinhança; tais laços são o elo que transforma uma coleção de vizinhos em uma vizinhança, um grupo social capaz de formar organizações locais em defesa contra o crime, na mobilização com propósitos políticos, entre outros (Kuo et al., 1998b). No trabalho, a presença de árvores colaborou para que houvesse um maior sentimento de unidade ou coesão entre vizinhos, tornando-os seguros e, também, mais satisfeitos com o local em que moravam.

O fortalecimento da comunidade, por sua vez, contribuiu para a redução dos níveis de violência doméstica e decorrente demanda por serviços sociais públicos. De acordo com Sullivan \& Kuo (1996), as moradoras mencionaram usar uma maneira mais construtiva, menos violenta de conduzir conflitos nas suas casas, utilizando a razão mais frequientemente do que a violência severa com seus filhos e menor violência física com os companheiros. As dificuldades de se viver na extrema

\footnotetext{
${ }^{8}$ Cardia \& Shiffer (2000, p.9) afirmam que, "se as áreas pobres da região metropolitana de São Paulo diferenciam-se das áreas centrais degradadas das cidades norte-americanas, as consequiências quando a violência se faz presente e seus efeitos sobre as pessoas não parecem ser diferentes".
} 
pobreza tornariam as moradoras irritadas, impulsivas, na iminência de descarregar esses sentimentos nos outros. Nesses momentos, ter vizinhos e poder contar com o seu suporte significa ter uma maneira alternativa de conviver com frustrações.

Para os autores, num momento em que a atenção nacional estava focalizada em questões relativas à saúde pública, essas pesquisas sugeriram que árvores poderiam ajudar a tratar alguns dos mais relevantes problemas da sociedade atual. As árvores urbanas não são amenidades, mas parte essencial da infra-estrutura de qualquer cidade, e tão necessárias quanto ruas, esgoto e eletricidade, afirmam.

Para as pessoas de baixa renda que ali moram e que enfrentam um conjunto de dificuldades pessoais, os espaços arborizados ao ar livre amenizam 0 congestionamento domiciliar, oferecem espaços mais adequados e criativos às crianças, trazem saúde física e psicológica, aumentam a satisfação com seu local de moradia, colaboram para a redução de estresses cotidianos, além dos outros benefícios anteriormente mencionados. De acordo com Kuo et al. (1998b), um pequeno investimento na arborização dos espaços comunitários pode transformar essa região da cidade num local melhor para se viver, tanto física quanto socialmente.

De acordo com Schroeder (1987), a arborização exerce forte influência sobre o humor, as emoções e a satisfação das pessoas com o ambiente que as envolve. Essas influências subjetivas e psicológicas se constituem nos melhores benefícios que as árvores podem proporcionar à população urbana, ressalta.

A estética, um dos principais atributos das árvores, influencia o prazer das pessoas ou a sua preferência por determinados locais ou paisagens, tendo, por sua vez, efeito no estado emocional. Dessa forma, se a presença de árvores aumenta o prazer das pessoas, a tendência é que seu estado emocional se volte ao positivo (Ulrich, 1989). Paisagens arborizadas são mais do que simplesmente bonitas, acrescentam Schroeder \& Lewis (1991); elas evocam uma "resposta de 
relaxamento" naqueles que as vêem, sentimentos de serenidade, paz e tranqüilidade, proporcionando bem-estar psicológico às pessoas.

\footnotetext{
"Sabemos, intuitivamente, que o contato com flores e plantas faz bem à saúde. Quase ninguém duvida de que a jardinagem - ou a simples contemplação de uma paisagem - traz renovação física $e$ mental. Mas, como explicar esse efeito?" (artigo "Mais verde, menos estresse", 2003, p.32).
}

De acordo com Schroeder (1987), uma expressão mais específica dessa idéia é a suposição de que árvores e outros elementos da natureza são psicologicamente saudáveis ao homem, e podem ajudar na redução de estresses associados à vida urbana.

O estresse, além das manifestações psicológicas, possui uma dimensão fisiológica 9 que pode ser mensurada através de indicadores cientificamente confiáveis. Dessa forma, Ulrich ${ }^{10}$, citado por Schroeder \& Lewis (1991), pode avaliar a "resposta de relaxamento" evocada pela arborização, fisiologicamente, submetendo pessoas a imagens visuais contendo cenas de natureza e tipicamente urbanas, sem vegetação. As pessoas que observaram cenas de natureza tiveram batimentos cardíacos mais lentos, menor pressão arterial e um padrão de ondas cerebrais mais relaxado do que aquelas que observaram cenas urbanas sem vegetação. Todos se recuperaram cerca de 4 a 6 minutos após a exposição às cenas, sugerindo que, para a reversão de certos níveis de estresse, tais como aborrecimentos diários ou irritações, o contato com a vegetação, ainda que breve ou através da exposição passiva, é benéfico. Para Ulrich (1989), os resultados dessa

\footnotetext{
9 Segundo os autores, consiste de reações vitais de muitos sistemas do corpo, como o cardiovascular, que prepara o indivíduo para enfrentar ou suportar uma sobrecarga ou situação desafiadora.

10 ULRICH, R.S. Natural versus urban scenes: some psychophysiological effects.
} Environment and Behavior, n.13, p. 523-556, 1981. 
pesquisa devem ser aplicados em ambientes estressantes da vida real, como hospitais e prisões.

Os benefícios psicológicos e fisiológicos proporcionados pelas árvores, segundo Ulrich (1989), podem ser usufruídos pelas pessoas em muitas situações, através do contato ativo, como plantio de árvores, crianças nelas trepando, e da exposição passiva, como experiências visuais ao observar árvores de rua, olhá-las através de janelas ou, simplesmente, andar em um parque arborizado. 


\section{METODOLOGIA}

O estudo foi realizado no município de Piracicaba, estado de São Paulo, localizado a $71 \mathrm{~km}$ da cidade de Campinas e a $152 \mathrm{~km}$ da cidade São Paulo, capital.

De acordo com o IBGE (Censo 2000), a população total do município é de 329.158 habitantes, dos quais 317.374 residem na área urbana e 11.784, na área rural. A área territorial é de $1.368,40 \mathrm{~km}^{2}$ (área urbana $-165,33 \mathrm{~km}^{2}$ e a rural de $1.203,07 \mathrm{~km}^{2}$ ), representando o $19^{\circ}$ município do estado em extensão ${ }^{11}$.

O rendimento dos chefes de família em Piracicaba nos anos de 1991 e 2000, por faixas de renda, é a seguinte:

Tabela 1. Rendimento dos chefes de família em Piracicaba

\begin{tabular}{lcc}
\hline Faixa salarial & 1991 & 2000 \\
\hline até $1 / 2$ SM & $2,73 \%$ & $0,20 \%$ \\
$>1 / 2$ SM até 3 SM & $43,45 \%$ & $31,91 \%$ \\
$>3$ SM até 5 SM & $21,12 \%$ & $21,80 \%$ \\
$>5$ SM até 10 SM & $18,60 \%$ & $24,62 \%$ \\
$>10 S M$ & $12,01 \%$ & $16,08 \%$ \\
\hline
\end{tabular}

Fonte: Fundação SEADE

Foram definidas duas etapas a serem cumpridas: i. a definição da área representativa para o estudo, segundo as estatísticas disponiveis sobre a violência urbana - em especial daquela que envolve crianças e adolescentes - no município; ii.

\footnotetext{
${ }^{11}$ Informações obtidas através do site www.ipplap.com.br, acesso em 08 jan 2005.
} 
análise dos sistemas de lazer desta área, caracterizada como "a mais violenta" do município.

Para o cumprimento da primeira etapa, optou-se por levantar informações que apontassem para a área "mais violenta" do município, ou aquela de maior procedência das crianças e adolescentes envolvidos com a violência; $e$, para a segunda, foram levantados dados referentes à oferta de sistemas de lazer na área de estudo definida.

\subsection{Dados sobre a violência e a definição da área de estudo}

Em entrevista realizada com a coordenação do Conselho Tutelar ${ }^{12}$ de Piracicaba, observou-se a existência de sigilo quanto aos dados referentes à violência envolvendo crianças e adolescentes ${ }^{13}$.

Desta forma, as duas fontes de dados que permitiram definir a área representativa para o estudo proposto foram indicadas pela Promotoria de Justiça da Infância e Juventude da Comarca de Piracicaba. São elas: os i. dados do projeto "Acolhimento à criança e ao adolescente em situação de rua"; e os ii. dados da organização não-governamental Serviço de Apoio ao Menor de Piracicaba (SEAME).

O projeto "Acolhimento à criança e ao adolescente em situação de rua" teve origem no encaminhamento, por parte do poder público, de ações referentes à problemática do alto índice de crianças e adolescentes, em situação de rua, na

12 Trata-se de um órgão municipal, previsto pelo Estatuto da Criança e do Adolescente, encarregado pela sociedade de zelar pelo cumprimento dos direitos da criança e do adolescente.

${ }^{13}$ De acordo com o Art. 2 do Estatuto da Criança e do Adolescente, instituído pela Lei $n^{\circ}$ 8.069, de 1990 e para todos os seus efeitos, considera-se criança a pessoa até doze anos de idade incompletos, $e$ adolescente aquela entre doze $e$ dezoito anos de idade. Excepcionalmente, nos casos expressos em lei, o Estatuto pode ser aplicado às pessoas entre dezoito e vinte e um anos. 
região central da cidade, e é uma parceria entre a Secretaria Municipal de Desenvolvimento Social (SEMDES) e a organização não-governamental Centro Regional de Registros e Atenção aos Maus Tratos na Infância de Piracicaba $(\text { CRAMI) })^{14}$.

Ele visa ao resgate e ao fortalecimento de vínculos familiares, à conquista da cidadania e prevê, grosso modo, dois momentos de intervenção. Num primeiro momento, os menores em situação de rua são abordados por educadores que, utilizando uma metodologia específica, detectam informações preliminares $e$ elaboram um relatório que é enviado ao CRAMI, cuja atenção está voltada às relações intrafamiliares. Num segundo momento, os técnicos de serviço social e psicologia daquela organização efetuam entrevistas domiciliares, nas quais procuram-se levantar dados relativos ao histórico familiar, situação socioeconômica, dificuldades, potencialidades e outras informações que possam subsidiar estudo e diagnóstico de cada caso.

Só então são feitos os encaminhamentos necessários do menor aos recursos do município, como creches, fórum, unidades de saúde e de serviço social, escolas, cursos profissionalizantes, unidades de recuperação, entre outros. Os pais ou responsáveis são convidados a participar dos grupos de família, cuja proposta é trabalhar a elevação da auto-estima e a reflexão sobre o seu papel na educação dos filhos.

Os dados aqui utilizados foram fornecidos pelo coordenador do projeto, em julho de 2003, e constam de dois relatórios de atividades que retratam tanto o primeiro momento de intervenção (no período compreendido entre janeiro $e$

${ }^{14}$ Um estudo prévio levantou dados oficiais de jovens internados na "Fundação Estadual do Bem-Estar do Menor" (FEBEM) devido a atos infracionais que cometeram; o número de crianças e adolescentes em conflito com a lei autuados nas delegacias da cidade; e o número de crianças e adolescentes em situação de rua - através dos quais foi possível avaliar a situação do menor na região de Piracicaba como não satisfatória, dando base à implantação do referido projeto. 
dezembro de 2002), como o segundo (no período compreendido entre outubro de 2001 e dezembro de 2002), a partir dos quais procurou-se reunir informações que compusessem o perfil das crianças e adolescentes em situação de rua, de sua situação familiar e, principalmente, que apontasse seu local de procedência.

O segundo grupo de dados aqui explorados, obtidos junto à organização nãogovernamental Serviço de Apoio ao Menor de Piracicaba (SEAME), remetem à realidade do menor infrator.

O SEAME teve início em 1981, como projeto da Diocese de Piracicaba e da Faculdade de Serviço Social (denominado Projeto de Liberdade Orientada para Menores Infratores), com a finalidade de atender adolescentes primários, autores de atos infracionais leves. A partir de 1988, a entidade vinculou-se juridicamente à Pastoral do Serviço da Caridade (PASCA), instituição criada pela Diocese de Piracicaba, conveniada à FEBEM (Fundação Estadual do Bem-Estar do Menor), mantendo vínculo com a Vara da Infância e da Juventude da Comarca de Piracicaba.

São encaminhadas à entidade as crianças e adolescentes aos quais foram aplicadas medidas socioeducativas da Liberdade Assistida (Art. 118), da Prestação de Serviços à Comunidade (Art. 117) e, também, da medida de proteção referente a Orientação, Apoio e Acompanhamento Temporário ${ }^{15}$ (Art. 101, inciso II), pelo Juiz da Vara da Infância e da Juventude da Comarca de Piracicaba, todas previstas no Estatuto da Criança e do Adolescente (Lei $n^{\circ} 8.069$, de 1990) ${ }^{16}$, no qual são detalhadas.

150 encaminhamento pode ser efetuado tanto judicialmente quanto pela própria comunidade, muito comum no caso de irmãos dos jovens que estão em cumprimento das medidas socioeducativas, considerados em "situação de risco".

${ }^{16}$ Maior detalhamento, consultar BRASIL, Leis, Decretos, etc. Lei $n^{\circ} 8.069$, de 13 de julho de 1990. Estatuto da criança e do adolescente. Disponivel em www.presidencia.gov.br/sedh. Acesso em 07 dez 2004. 
O trabalho da entidade é desenvolvido por técnicos de serviço social e psicologia através de acompanhamento individual dos jovens, sendo efetuados os devidos encaminhamentos necessários a unidades de saúde e de atendimento psiquiátrico, escolas, retirada de documentos, emprego, às instituições onde cumprirão a medida de prestação de serviços à comunidade e, também, familiar, através de visitas domiciliares, atendimento em grupo de mães e reunião mensal com os pais ou responsáveis pelo menor. $O$ atendimento familiar é estendido às famílias cujos filhos são internos da FEBEM.

Os dados sobre o menor em cumprimento das medidas socioeducativas da Liberdade Assistida (Art. 118) e da Prestação de Serviços à Comunidade (Art. 117) foram coletados junto ao psicólogo e às assistentes sociais da entidade e referemse ao período compreendido entre janeiro e dezembro de 2002. O levantamento exigiu bastante tempo - de maio a setembro de 2003 - devido à falta de sistematização das informações (que exigiu a análise dos arquivos de cada menor) $e$ à pouca disponibilidade de tempo dos técnicos da instituição, dado o grande volume diário de jovens atendidos.

Considerada a relativa precariedade dos dados socioeconômicos mais gerais, procurou-se reunir informações que compusessem o perfil do menor infrator, de sua situação familiar e, principalmente, apontasse seu local de procedência. Ao final da coleta, os dados foram organizados em planilhas e sistematizados com os recursos do Excel, apresentados no Capítulo 4 desta dissertação.

Tendo em mãos as estatísticas obtidas junto a essas fontes, pode-se definir a área de interesse de estudo.

Para a sua caracterização mais geral, contou-se, ainda, com informações obtidas através de pesquisa documental e entrevistas com diversos membros da Secretaria Municipal de Desenvolvimento Social e do Instituto de Pesquisas e Planejamento de Piracicaba - IPPLAP, bem como das organizações não- 
governamentais SEAME e CRAMI, sendo que esta última, através do projeto "Acolhimento à criança e ao adolescente em situação de rua", possibilitou o acompanhamento de atividades in loco.

\subsection{Levantamento de dados sobre os sistemas de lazer da área de estudo}

Os dados sobre a oferta de sistemas de lazer foram levantados a partir de análise de mapa fornecido pela Prefeitura do Município de Piracicaba (Anexo A. Diagnóstico das áreas públicas destinadas para sistemas de lazer e institucional Dados do Bairro Mário Dedini, escala 1:10.000), cuja base cartográfica foi elaborada a partir de levantamento aerofotogramétrico realizado em 1995.

O mapa utilizado faz parte de amplo cadastramento dos sistemas de lazer da cidade, realizado em resposta a uma ação civil pública que questionou o cumprimento do estabelecido na Lei Orgânica do Município, referente ao oferecimento de $10 \mathrm{~m}^{2}$ de área verde por habitante. Além disso, no ano de 2003, quando das discussões para a revisão do Plano Diretor de Desenvolvimento Urbano de Piracicaba, a Coordenação do Orçamento Participativo apontou como uma das principais solicitações dos moradores a demanda para a implantação de áreas públicas voltadas ao lazer, sobretudo na periferia da cidade, justificando ainda mais a publicação deste cadastramento (Piracicaba, 2004).

Em posse dos dados sobre a oferta de sistemas de lazer, buscou-se conferir sua existência na área de estudo, verificando, com visitas ao local, se estão realmente sendo utilizados para os fins pretendidos.

Baseando-se nas designações da Prefeitura do Município de Piracicaba e de Cavalheiro et al. (1999), mencionadas no item 2.3, nesse estudo, sistema de lazer e espaço livre de construção público foram considerados sinônimos. 


\section{RESULTADOS E DISCUSSÃO}

\subsection{A violência no município de Piracicaba-SP}

\subsubsection{Dados do projeto "Acolhimento à criança e ao adolescente em situação de rua"}

Durante o período de janeiro a dezembro de 2002, foram identificados 262 crianças e adolescentes em situação de rua no município de Piracicaba, dos quais 180 foram o alvo de intervenção do referido projeto (Piracicaba, 2002a). As informações acerca da situação familiar contemplada pelo mesmo se referem ao atendimento de 90 famílias, assistidas entre outubro de 2001 e dezembro de 2002. A partir da análise dos relatórios de atividades, verificou-se:

\section{a) $O$ perfil das crianças e adolescentes em situação de rua}

A condição socioeconômica é a principal causa da ida das crianças e adolescentes às ruas, fazendo com que vão buscar uma complementação de renda ou até mesmo constituí-la, através de atividades como "guardar" carros, pedir esmola nos principais cruzamentos, vender balas, flores ou outros objetos, entregar panfletos, coletar recicláveis. Há, ainda, outras condições que os impulsionam para as ruas: a deterioração dos laços familiares e a violência doméstica (Piracicaba, 2002a). Nas ruas, expostos aos perigos que estas podem oferecer, não raramente 
adentram o mundo do vício (drogas, prostituição) e do crime em seus diferentes níveis, desde a prática de pequenos furtos até homicídios, latrocínio, entre outros (CRAMI, 2002; Piracicaba, 2002a).

Nos documentos levantados, não foi observada menção sobre o sexo da população atendida. A sua distinção, por faixa etária é apresentada na Tabela 2.

Tabela 2. Faixa etária das crianças e adolescentes em situação de rua

\begin{tabular}{lcc}
\hline Faixa Etária & $N^{\circ}$ de Atendidos & $\%$ \\
\hline De 7 a 12 anos & 79 & 43,9 \\
De 13 a 15 anos & 58 & 32,2 \\
De 16 a 17 anos & 33 & 18,3 \\
De 18 ou mais & 4 & 2,2 \\
Sem registro & 6 & 3,3 \\
Total & 180 & 100 \\
\hline
\end{tabular}

Fonte: Piracicaba (2002a)

A Tabela 3 apresenta a escolaridade das crianças e adolescentes. Piracicaba (2002a) ressalta que, quando questionados, todos os meninos e meninas se referiram a uma escolaridade, mas constatou-se que poucos sabiam ler.

Tabela 3. Escolaridade das crianças e adolescentes em situação de rua

\begin{tabular}{lcc}
\hline \multicolumn{1}{c}{ Escolaridade } & $N^{\circ}$ de Atendidos & $\%$ \\
\hline De $5^{a}$ a $8^{a}$ série & 93 & 51,7 \\
De $1^{a}$ a $4^{a}$ série & 68 & 37,7 \\
Ensino médio incompleto & 3 & 1,7 \\
Sem escolaridade & 3 & 1,7 \\
Sem registro & 13 & 7,2 \\
Total & 180 & 100 \\
\hline
\end{tabular}

Fonte: Piracicaba (2002a) 
Nas ruas, as principais atividades desenvolvidas são: trabalho $(31,6 \%)$, mendicância $(27,8 \%)$, mendicância e uso de drogas (25,6\%), uso de drogas $(2,8 \%)$, sendo os $12,2 \%$ restantes referentes às crianças e adolescentes sobre os quais não se pode obter informação.

\section{b) Procedência e situação familiar das crianças em situação de rua}

Os bairros de origem das crianças e adolescentes para as ruas são

"[...] bairros periféricos, recém-formados ou com equipamentos sociais precários ou inexistentes, com programas sócio-educativos insuficientes para o atendimento às demandas [...]" (CRAMI, 2002, p.8).

Identificou-se o loteamento Bosques do Lenheiro como o local de maior procedência da população atendida $(34,5 \%)$ e, logo em seguida, o Jardim Monte Líbano (18,5\%), localizados nas Regiões Norte e Sul do município, respectivamente. No Anexo B, podem ser observadas todas as localidades de origem, com as suas respectivas representatividades.

É interessante notar que, segundo informações levantadas no Instituto de Pesquisas e Planejamento de Piracicaba - IPPLAP, essas localidades são, em geral, loteamentos de interesse social (Bosques do Lenheiro, Jardim Novo Horizonte, Jardim Vitória, Jardim Oriente, Parque dos Sabiás e Mário Dedini), sendo somente uma classificada como sistema de lazer invadido no passado que, hoje, já possui situação consolidada (Jardim Glória).

A situação de moradia das crianças e adolescentes é bem contrastante: enquanto pouco mais que a metade das famílias (56\%) mora em casa própria de alvenaria, o restante vive em casa de alvenaria invadida $(5,5 \%)$, casa de alvenaria com agregados (4,5\%), casa de alvenaria alugada (4,5\%) ou, ainda, em barraco 
próprio de madeira (19,5\%), barraco cedido de madeira (6\%) e barraco alugado (4\%), conforme o Anexo $C$.

As famílias, em geral, são consideravelmente numerosas (Anexo D), sendo que apenas $9 \%$ delas possuem menos que 5 membros. Contribui para que isso ocorra, de acordo com o CRAMI (2002), o fato de haver uma freqüente troca de parceiros nessa população.

Como refere o CRAMI (2002, p.4), nos bairros periféricos mora-se, na maior parte das vezes, "[...] em sub-habitação ou casas de alvenaria precárias e insuficientes para abrigar as famílias [...]", o que equivale a dizer que possuir uma casa de alvenaria não significa ter um local adequado para se viver, ou mesmo qualidade de vida familiar, já que o congestionamento domiciliar, ou excesso de pessoas por moradia, por si, implica perda de privacidade, criando ambiente propício para o surgimento de desgaste das relações e conflitos entre os membros da família.

Os pais ou responsáveis pelas crianças e adolescentes possuem elevado índice de analfabetismo. A situação de desemprego também é grande, principalmente para pais, padrastos e mães arrimo de família. As atividades desenvolvidas, além de mal remuneradas, não exigem maior qualificação, como catadores de materiais recicláveis (45\%), trabalhadores da construção civil (16\%), serviços domésticos (14\%), vendedores ambulantes (10\%), guardadores de veículos (7\%), trabalhos sazonais (5\%) e marceneiros (3\%).

Segundo o CRAMI (2002), a renda per capita é insuficiente à sobrevivência, considerando-se que a renda familiar de 39\% dessa população é menor que 1 salário mínimo, conforme o Anexo E. Como alternativa de sobrevivência, permite-se e, não raramente estimula-se aos filhos praticarem a mendicância e outras atividades nas ruas.

Verificou-se, também, que nessas famílias atendidas 
"[...] os maus-tratos praticados contra crianças e adolescentes estão relacionados com a situação de pobreza, principalmente quando se fazem presentes outros componentes como o alcoolismo e a drogadição" (CRAMI, 2002, p.6).

A esse respeito, a entidade ressalta que, embora o número de casos não declarados seja elevadíssimo, foram identificadas 29 famílias que afirmaram existir pelo menos 1 elemento (pai, padrasto ou mãe) usuário de drogas ou álcool (inaláveis, injetáveis, entre outros) ou ambos.

\subsubsection{Dados da organização não-governamental Serviço de Apoio ao Menor de Piracicaba (SEAME)}

Durante o período de janeiro a dezembro de 2002, foram atendidos pelo SEAME 242 jovens, encaminhados pelo Juiz da Vara da Infância e da Juventude da Comarca de Piracicaba, para o cumprimento das medidas socioeducativas da Liberdade Assistida e da Prestação de Serviços à Comunidade. A partir dos dados coletados acerca desses jovens, verificou-se:

\section{a) $O$ perfil do jovem infrator}

Do total de jovens infratores atendidos pela instituição, $90,9 \%$ são do sexo masculino e $9,1 \%$, do sexo feminino.

A idade varia bastante, do menor de 13 anos até aqueles que ultrapassam os 18 anos, sendo que a maior parte deles possui entre 16 e 18 anos $(65,7 \%)$, como pode ser observado na Figura 1. 


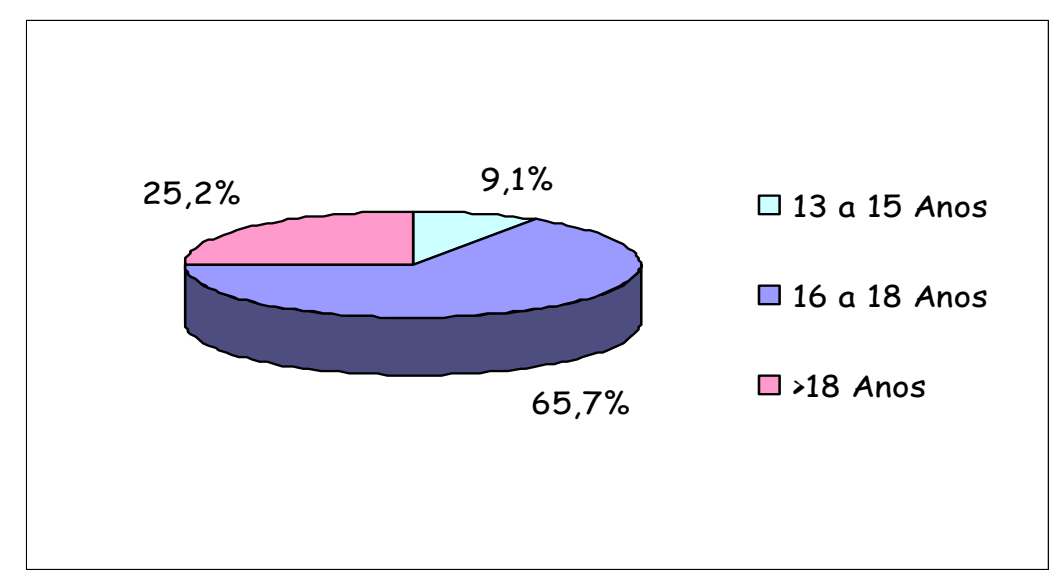

Figura 1 - Faixa etária dos jovens infratores

Fonte: Elaboração pela autora

O uso de drogas é uma característica marcante dessa população, já que $56,6 \%$ dos jovens se declaram usuários, $28,5 \%$ não usuários e $14,9 \%$ não deram essa informação.

Procurou-se conhecer o cotidiano dos jovens. Constatou-se que a maior parte deles declarou não exercer nenhum tipo de atividade (Figura 2) - o que remete às reflexões de Castro et al. (2001), acerca de dados de pesquisas sobre educação e trabalho, no Brasil, que indicam que os jovens fora da escola não necessariamente se encontram ocupados no mercado de trabalho e vice-versa, e questionam

\footnotetext{
"o que fazem esses jovens com o tempo ocioso? E o que fazem com - que se convencionou chamar de "tempo livre" os que trabalham e estudam, ou os que só estudam? Contam com oportunidades de lazer, de envolvimento com atividades esportivas ou com práticas culturais?" (Castro et al., 2001, p.55).
} 


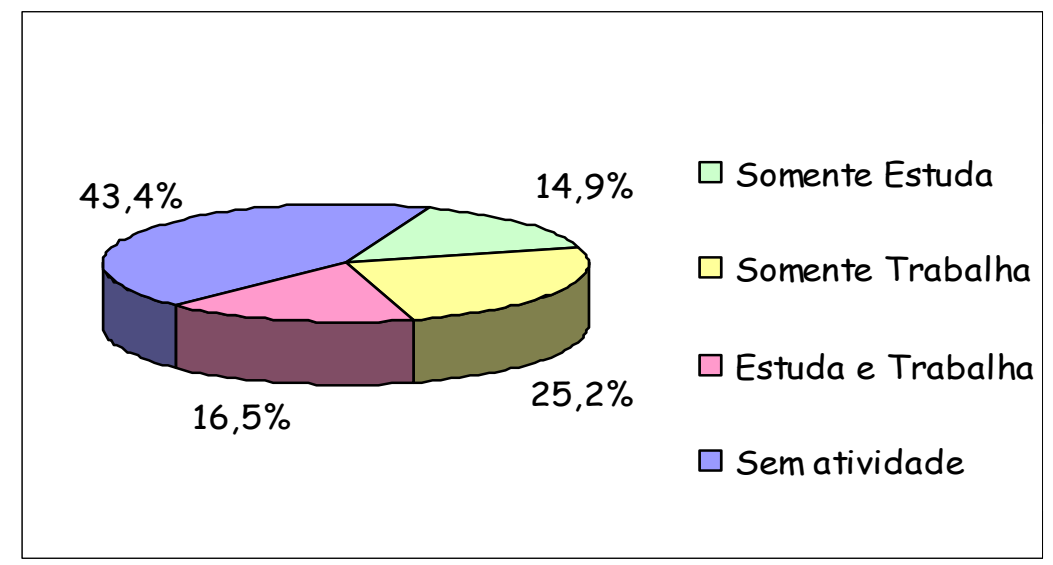

Figura 2 - Atividade cotidiana dos jovens infratores Fonte: Elaboração pela autora

Dos jovens trabalhadores cuja renda foi declarada à entidade, $20 \%$ recebiam menos que 1 salário mínimo, 73,3\% recebiam entre 1 e 3 salários mínimos e 6,7\% recebiam de 3 a 6 salários mínimos ${ }^{17}$.

Praticamente nenhum dos jovens que trabalhavam possuíam vínculo empregatício. Os trabalhos desenvolvidos eram de panfletagem, como servente de pedreiro, monitor de informática, entregador de pizzas, "bicos", como funileiro, pintor automotivo, garçom, ajudante geral, montagem de som, lavador de carros ou motos, jardineiro, "guardador" de carro nas ruas, ajudante de pintor, manicure, auxiliar de mecânica, Projeto Reciclar, técnico contábil ou outros trabalhos como: copeiro do Habib's, curtume, comércio, mercado municipal, corte da cana-de-açúcar, fábrica de urnas, aterro sanitário e em montadora de móveis.

Quanto aos atos infracionais, a entidade classificava-os em 32 tipos, sendo o furto o mais freqüentemente cometido pelos jovens (Tabela 4). Ainda, com relação ao número de infrações cometidas, $97,5 \%$ dos jovens cometeram 1 ato infracional, $1,2 \%$ cometeram 2 atos infracionais e 1,2\% cometeram 3 atos infracionais.

17 Tendo como valor de referência $R \$ 240,00$. 
Tabela 4. Infrações cometidas pelos jovens infratores

\begin{tabular}{|c|c|c|}
\hline Tipo de ato Infracional ${ }^{\star \star}$ & Infrações Cometidas & $\%$ \\
\hline Furto & 93 & 37,5 \\
\hline Roubo simples & 35 & 14,1 \\
\hline Porte ou uso de drogas & 23 & 9,3 \\
\hline Dano & 16 & 6,5 \\
\hline Lesão corporal & 16 & 6,5 \\
\hline Tráfico de drogas & 16 & 6,5 \\
\hline Roubo qualificado & 14 & 5,6 \\
\hline Porte de arma & 7 & 2,8 \\
\hline Ameaça & 6 & 2,4 \\
\hline Dirigir sem habilitação & 4 & 1,6 \\
\hline Homicídio doloso & 4 & 1,6 \\
\hline Homicídio culposo & 3 & 1,2 \\
\hline Receptação & 3 & 1,2 \\
\hline Estelionato/outras fraudes & 2 & 0,8 \\
\hline Calúnia/difamação/injúria & 1 & 0,4 \\
\hline Desacato & 1 & 0,4 \\
\hline Descumprimento da medida & 1 & 0,4 \\
\hline Estupro & 1 & 0,4 \\
\hline Latrocínio & 1 & 0,4 \\
\hline Vias de fato & 1 & 0,4 \\
\hline Aborto & 0 & 0,0 \\
\hline Apropriação indébita & 0 & 0,0 \\
\hline Atentado violento ao pudor & 0 & 0,0 \\
\hline Ato obsceno & 0 & 0,0 \\
\hline Extorção & 0 & 0,0 \\
\hline Falsidade ideológica & 0 & 0,0 \\
\hline Formação de bando & 0 & 0,0 \\
\hline Infanticídio & 0 & 0,0 \\
\hline Rixa & 0 & 0,0 \\
\hline Seqüestro/cárcere privado & 0 & 0,0 \\
\hline Violação de domicílio & 0 & 0,0 \\
\hline Uso de documentos falsos & 0 & 0,0 \\
\hline Total & 248 & 100 \\
\hline
\end{tabular}

Fonte: Elaboração pela autora

*Infrações cometidas no período de janeiro a dezembro de 2002.

${ }^{* *}$ Segundo a entidade, todos os atos infracionais encontram-se detalhados no Código de Direito Penal. 
As medidas socioeducativas são aplicadas pelo Juiz de acordo com as infrações cometidas. Desse modo, verifica-se que $78,4 \%$ dos jovens estão em cumprimento da medida da Liberdade Assistida e 21,6\%, da Prestação de Serviços à Comunidade, sendo que a primeira refere-se às infrações mais graves.

\section{b) Situação familiar do jovem infrator}

As informações acerca da situação familiar não puderam ser obtidas para todos os jovens, dada a relativa precariedade dos dados socioeconômicos da entidade.

A renda familiar dos jovens varia consideravelmente (Figura 3). Desconsiderando-se a alta parcela da população que não cedeu essa informação, a maior parte das famílias tem renda entre 1 e 3 salários mínimos.

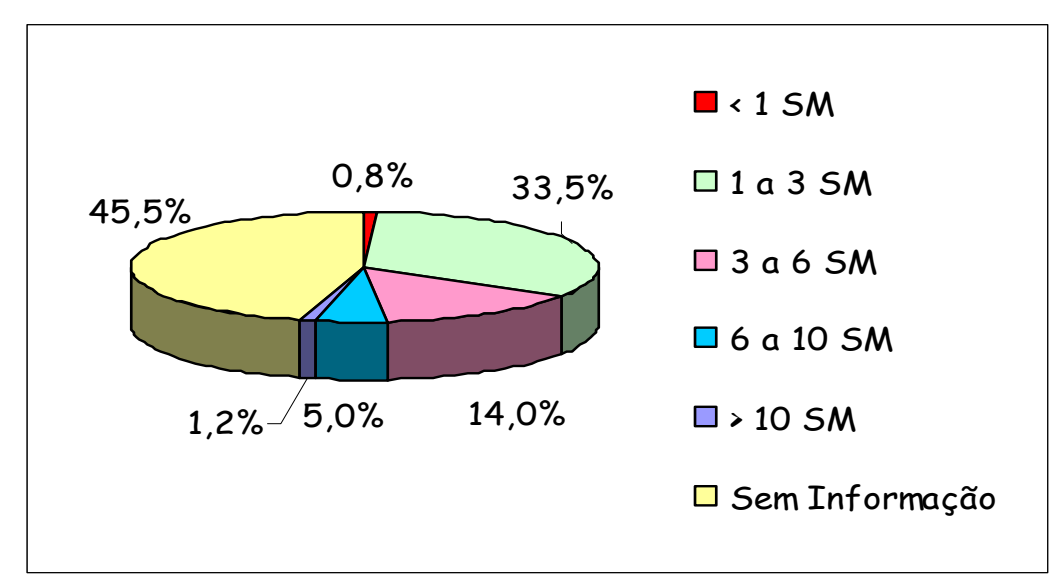

Figura 3 - Renda familiar ${ }^{*}$ dos jovens infratores

Fonte: Elaboração pela autora

"Salário mínimo (SM) de referência - $R \$ 240,00$; Intervalos fechados à esquerda (de 0 a 1 salário mínimo, exclusive, de 1 a 3 salários mínimos, exclusive, e assim por diante).

A maior parte das famílias possui casa própria $(68,6 \%)$, mas há aquelas que moram em casa alugada $(13,6 \%$ e em casa cedida por parentes (7\%). Para cerca de $10,7 \%$ dos jovens não foi possivel obter essa informação. Ainda a esse respeito, 
verificou-se o número de pessoas existentes por moradia (Figura 4), o que, de maneira geral, demonstra a existência de um alto congestionamento domiciliar.

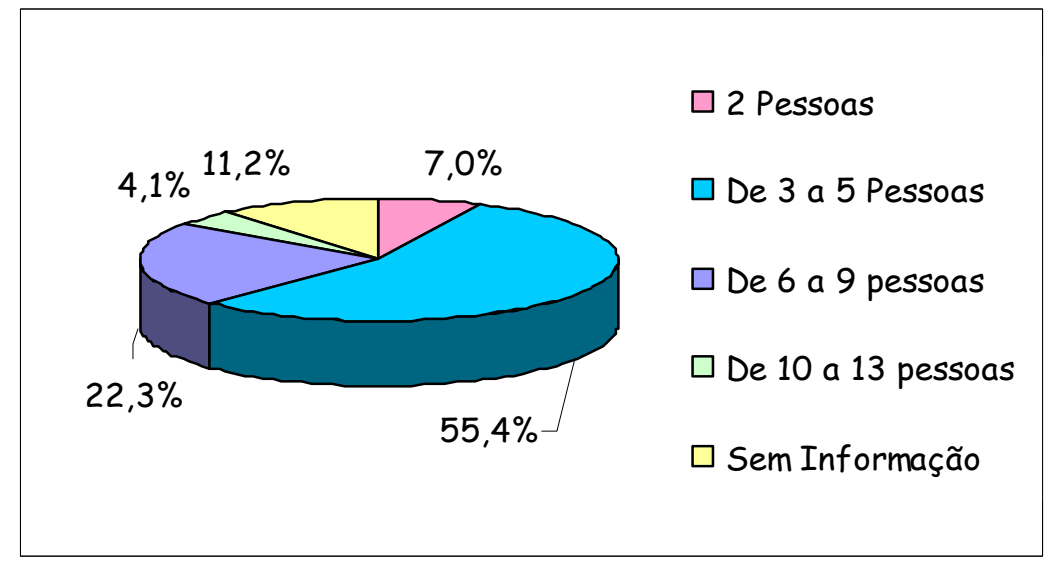

Figura 4 - Número de pessoas existentes por moradia dos jovens infratores Fonte: Elaboração pela autora

\section{c) Procedência do jovem infrator}

Dos 242 jovens infratores atendidos pelo SEAME, $238(98,3 \%)$ são do município de Piracicaba e 4 (1,7\%) do município de Charqueada.

No município de Piracicaba, observou-se que $98,7 \%$ dos jovens são provenientes da Zona Urbana, com destaque à Região Norte (Figura 5) que é a mais representativa $(31,5 \%)$.

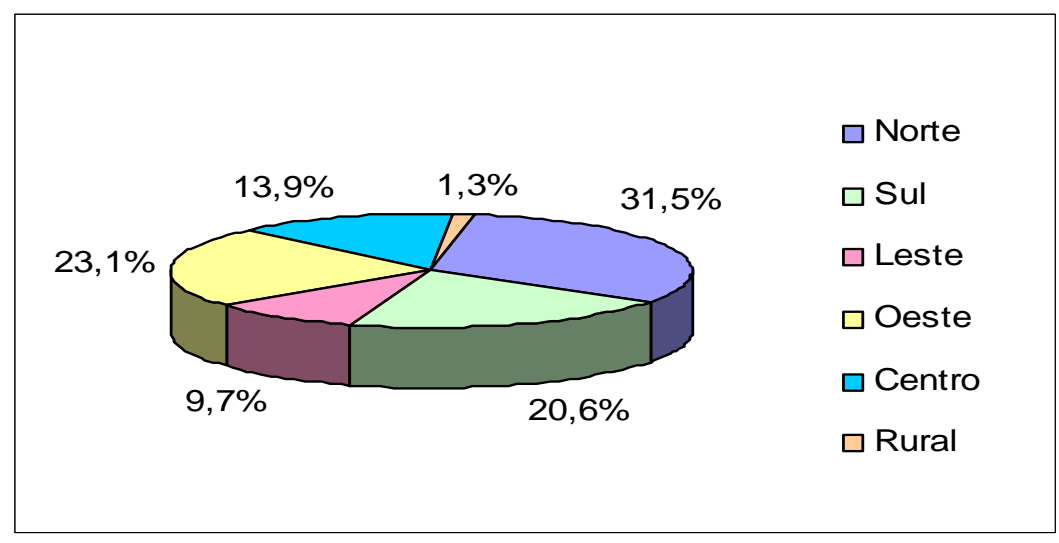

Figura 5 - Distribuição dos jovens infratores por região do município de Piracicaba Fonte: Elaboração pela autora 
No município, ao todo, foram identificados 68 locais de procedência (Tabela 5) desses jovens, onde o loteamento Bosques do Lenheiro se sobressai com $9,2 \%$.

Tendo verificado no item anterior que, embora a situação familiar dos jovens varie consideravelmente, há predomínio de famílias de baixa renda e um número alto de pessoas existentes por moradia, procurou-se identificar, junto ao IPPLAP Instituto de Pesquisas e Planejamento de Piracicaba, mais algumas características desses empreendimentos, tais como se são loteamentos de interesse social, áreas invadidas por favelas, entre outros - sintetizados na Tabela 5.

Tabela 5. Procedência dos jovens infratores no município de Piracicaba

\begin{tabular}{|c|c|c|c|}
\hline Local de Procedência & Característica & $\begin{array}{l}N^{0} \text { de } \\
\text { Jovens }\end{array}$ & $\%$ \\
\hline Bosques do Lenheiro & Loteamento de interesse social & 22 & 9,2 \\
\hline Paulicéia & & 13 & 5,5 \\
\hline Bairro Alto & & 11 & 4,6 \\
\hline Centro & & 11 & 4,6 \\
\hline Santa Terezinha & & 11 & 4,6 \\
\hline Jardim Boa Esperança & Loteamento de interesse social ${ }^{*}$ & 10 & 4,2 \\
\hline Monte Líbano & Loteamento de interesse social & 9 & 3,8 \\
\hline Algodoal & Área invadida & 7 & 2,9 \\
\hline Vila Rezende & & 7 & 2,9 \\
\hline Jardim Maria Claudia & & 6 & 2,5 \\
\hline Novo Horizonte & Loteamento de interesse social ${ }^{*}$ & 6 & 2,5 \\
\hline Tatuapé II & & 6 & 2,5 \\
\hline Vila Independência & & 6 & 2,5 \\
\hline Jaraguá & & 5 & 2,1 \\
\hline Jardim Esplanada & & 5 & 2,1 \\
\hline Jardim Ibirapuera & & 5 & 2,1 \\
\hline Jardim Vitória & Loteamento de interesse social & 5 & 2,1 \\
\hline Campestre & & 4 & 1,7 \\
\hline Jardim Planalto & & 4 & 1,7 \\
\hline Morumbi & & 4 & 1,7 \\
\hline Bairro Verde & & 3 & 1,3 \\
\hline Jardim Camargo & & 3 & 1,3 \\
\hline
\end{tabular}


Tabela 5. Procedência dos jovens infratores no município de Piracicaba

\begin{tabular}{|c|c|c|c|}
\hline Local de Procedência & Característica & $\begin{array}{l}N^{\circ} \text { de } \\
\text { Jovens }\end{array}$ & $\%$ \\
\hline Jardim Elite & & 3 & 1,3 \\
\hline Jardim Monte Cristo & & 3 & 1,3 \\
\hline Jardim Oriente & Loteamento de interesse social & 3 & 1,3 \\
\hline Kobayat-Líbano & & 3 & 1,3 \\
\hline Mário Dedini & Loteamento de interesse social & 3 & 1,3 \\
\hline Paulista & & 3 & 1,3 \\
\hline Vila Sônia & & 3 & 1,3 \\
\hline Bairro dos Alemães & & 2 & 0,8 \\
\hline CECAP II & Loteamento de interesse social & 2 & 0,8 \\
\hline Jardim Alvorada III & Loteamento de interesse social & 2 & 0,8 \\
\hline Jardim Borguesi & & 2 & 0,8 \\
\hline Jardim I†apuã & & 2 & 0,8 \\
\hline Jardim São Paulo & & 2 & 0,8 \\
\hline Jardim Tóquio & & 2 & 0,8 \\
\hline Maracanã & & 2 & 0,8 \\
\hline Nova América & & 2 & 0,8 \\
\hline Parque Orlanda III & & 2 & 0,8 \\
\hline Parque Prezotto & & 2 & 0,8 \\
\hline Tatuapé I & & 2 & 0,8 \\
\hline Vila Cristina & & 2 & 0,8 \\
\hline Vila Fátima & & 2 & 0,8 \\
\hline Vila Industrial & & 2 & 0,8 \\
\hline Água Branca & & 1 & 0,4 \\
\hline Anhumas & & 1 & 0,4 \\
\hline Castelinho & & 1 & 0,4 \\
\hline CECAP & Loteamento de interesse social & 1 & 0,4 \\
\hline Chácara Nazaré II & & 1 & 0,4 \\
\hline Distrito de Ártemis & & 1 & 0,4 \\
\hline Distrito de Tupi & & 1 & 0,4 \\
\hline Eldorado II & Loteamento de interesse social & 1 & 0,4 \\
\hline Ipês & & 1 & 0,4 \\
\hline Jardim Alvorada I & Loteamento de interesse social & 1 & 0,4 \\
\hline Jardim Colonial & & 1 & 0,4 \\
\hline Jardim Itamaracá & & 1 & 0,4 \\
\hline Jardim Primavera & & 1 & 0,4 \\
\hline
\end{tabular}


Tabela 5. Procedência dos jovens infratores no município de Piracicaba

\begin{tabular}{|c|c|c|c|}
\hline Local de Procedência & Característica & $\begin{array}{l}N^{\circ} \text { de } \\
\text { Jovens }\end{array}$ & $\%$ \\
\hline Jardim Residencial Javary I & & 1 & 0,4 \\
\hline Jardim Residencial Javary II & & 1 & 0,4 \\
\hline Jardim São Luiz & & 1 & 0,4 \\
\hline Nova Paulista & & 1 & 0,4 \\
\hline Nova Piracicaba & & 1 & 0,4 \\
\hline Parque Chapadão & & 1 & 0,4 \\
\hline Parque Orlanda II & & 1 & 0,4 \\
\hline Piracicamirim & & 1 & 0,4 \\
\hline Residencial Pq. Piracicaba (Balbo) & Loteamento de interesse social & 1 & 0,4 \\
\hline São Dimas & & 1 & 0,4 \\
\hline Vila Monteiro & & 1 & 0,4 \\
\hline Total & & 238 & 100 \\
\hline
\end{tabular}

Fonte: Elaboração pela autora

*Profilurb - a família recebia um lote com 1 banheiro e 1 tanque de lavar roupas.

Tendo em mãos as estatísticas obtidas junto às fontes, identificou-se o loteamento Bosques do Lenheiro como área de estudo, uma vez que, por ser o local de maior procedência de crianças e adolescentes em situação de rua, assim como de jovens infratores em cumprimento das medidas socioeducativas da Liberdade Assistida e da Prestação de Serviços à Comunidade, foi caracterizada como "a mais violenta" do município de Piracicaba.

\subsection{Conjunto Habitacional Bosques do Lenheiro}

\subsubsection{Localização e breve histórico}

Bosques do Lenheiro, Conjunto Habitacional Bosques do Lenheiro ou simplesmente "Bosques", como é popularmente conhecido, é um loteamento que pertence ao Bairro Mário Dedini (Figura 6), localizado na Região Norte do município 
de Piracicaba, próximo ao anel viário e das rodovias de acesso às cidades de Rio Claro, Limeira, São Pedro e Charqueada.

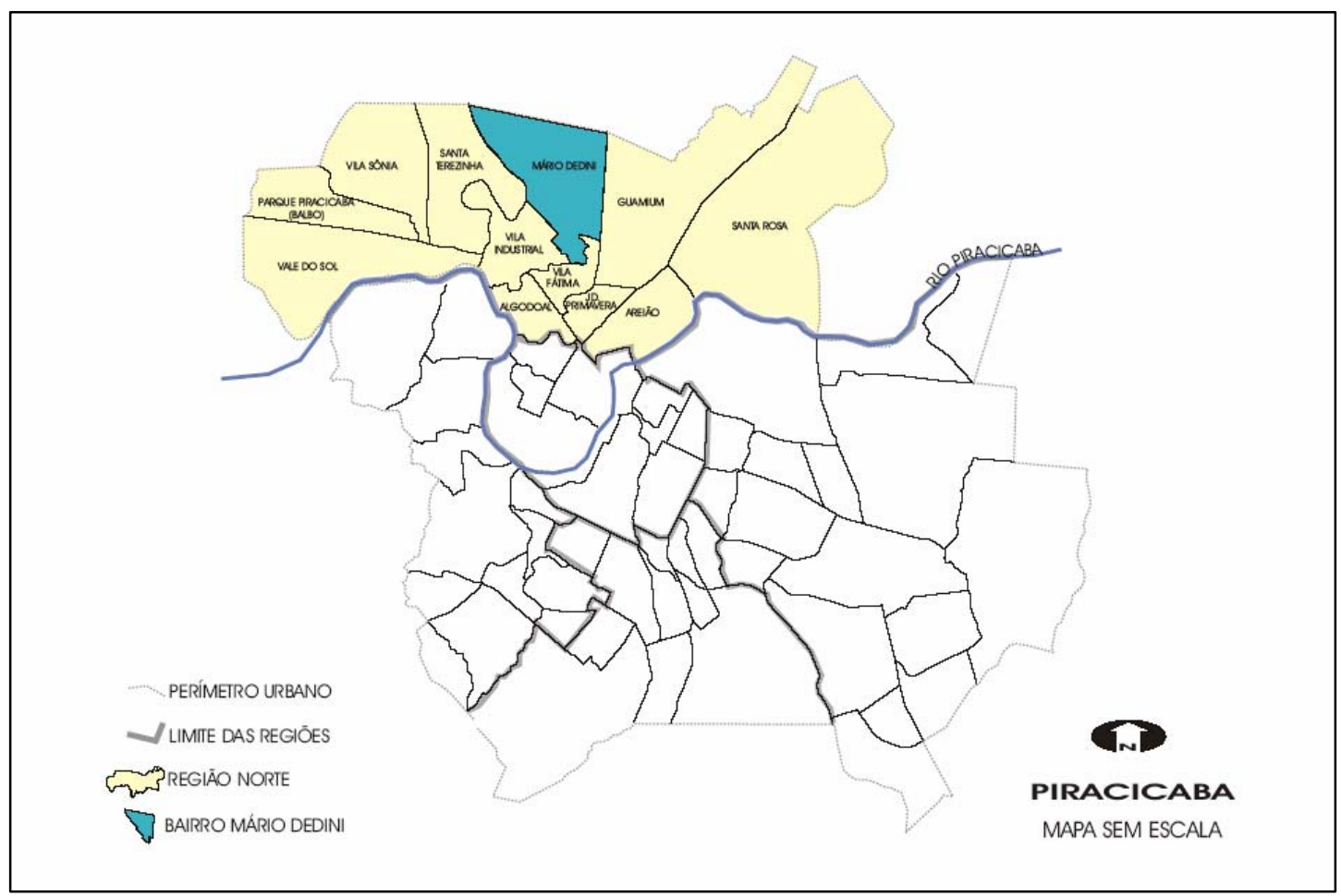

Figura 6 - Localização do Bairro Mário Dedini na Região Norte do município de Piracicaba

Fonte: Adaptado de Piracicaba (2004)

O loteamento de interesse social destina-se ao atendimento da população de menor renda no município, a qual não possui bens imóveis (Piracicaba, 1985). 0 Bosques do Lenheiro, como tal, foi planejado para atender 1.370 famílias de baixa renda residentes, principalmente nas favelas, áreas de risco e de preservação ambiental da cidade ${ }^{18}$. Foi viabilizado por uma parceria entre a Prefeitura, através da Empresa Municipal de Desenvolvimento Habitacional de Piracicaba (EMDHAP), e

${ }^{18}$ Nova Suíça, Guamium, Vila Maria, Belvedere, Nova Paulista, Enxofre e Jardim Conceição, Tatuapé II, Ponte do Caixão, Monte Branco, Vila Fátima, Santa Rosa, IAA, Diamante, Algodoal. 
a Caixa Econômica Federal, que financiou o empreendimento. De acordo com Piracicaba (2002b), a idéia inicial era de implementá-lo através do Programa "PróMoradia", em que cada um faz a sua casa. Entretanto, optou-se pela construção de uma casa ou "embrião".

O cadastramento das famílias a serem beneficiadas foi efetuado pela Secretaria Municipal de Desenvolvimento Social (SEMDES), no início do ano de 2000 e, antes mesmo que a obra fosse concluída, iniciou-se sua remoção e reassentamento, para que fossem evitadas depredações das moradias. Até o mês de setembro daquele ano, a transferência das famílias foi cumprida dentro do cronograma previsto. A partir da primeira quinzena de outubro, houve ausência de funcionários e de segurança dentro do loteamento, dando oportunidade às invasões. A empresa contratada para a sua execução abandonou o empreendimento e a população cadastrada, com receio de perder a oportunidade de conseguir um local de moradia, mudou-se para o Conjunto Habitacional, mesmo ele estando ainda sem infra-estrutura, como energia elétrica, por exemplo.

Um novo governo municipal tomou posse no ano de 2001 (gestão 2001-2004, Prefeito José Machado), encontrando, no local, diversas categorias de moradores (proprietários de direito, inscritos da EMDHAP, cadastrados de áreas verdes e áreas de risco, invasores, entre outros) e mais de 4.100 habitantes. Diante da escassez de informações socioeconômicas e a urgência em retomar a instalação de infra-estrutura no loteamento, a SEMDES efetuou um importante levantamento de dados a ser utilizado como instrumento de orientação das ações públicas. Porém, a tabulação desses dados não foi concretizada, impedindo a realização de um bom diagnóstico da situação atual (Piracicaba, 2002b).

Em abril de 2002, o loteamento passou a contar com o "Programa Municipal de Ações Integradas de Inclusão Social". Trata-se da integração de diversas secretarias e programas, visando a atender as regiões da cidade que apresentam os 
maiores índices de exclusão social, concentração de pobreza, escassez de recursos públicos diante da demanda, e vetores de crescimento que apontam para o agravamento da situação social. Os locais indicados como os mais pobres foram o Bosques do Lenheiro e o Parque dos Sabiás, localizados nas Regiões Norte e Oeste do município, respectivamente.

Segundo a SEMDES, esforços deveriam ser concentrados "[...] nos lugares em que os problemas se acumulam, ou seja, nas regiões e bairros mais carentes do município". Salienta, ainda, o significado dos termos carência - "[...] não possuir condições necessárias para a aquisição de bens e serviços necessários à sobrevivência" - e inclusão - "[...] participar ativamente das decisões e construção da comunidade" -, que juntos modelam o objetivo geral do programa, que é despertar o desenvolvimento de consciência comunitária, motivando a participação, visando ao atendimento das necessidades básicas e, conseqüentemente, melhoria na qualidade de vida da população, tornando mais forte a comunidade local, para que ela seja capaz de fazer valer os seus interesses, de controlar a ação social pública e também de disputar os recursos gerados na comunidade local. Dentre os objetivos específicos, menciona-se a necessidade de promover encontro com os moradores, visando à sua organização e auto-gestão ${ }^{19}$.

\subsubsection{Os moradores}

A população assentada no Conjunto Habitacional é bastante diversificada. Parte dela é proveniente de áreas consideradas de risco e de áreas verdes invadidas Há, ainda, sem-tetos, alguns casos excepcionais e famílias invasoras. Vale

19 Informações transmitidas no seminário "Proposta para a Jornada da Cidadania" apresentado por membros da SEMDES no segundo semestre de 2003, que gentilmente cederam cópia dos slides. 
ressaltar que estas últimas não são apenas do município de Piracicaba, mas de diversos locais do país, como pode ser constatado: da Região Sudeste - estado de São Paulo (Piracicaba e região) e estado de Minas Gerais (Novo Cruzeiro, Araçuaí); Região Nordeste - estados da Bahia, Pernambuco e Alagoas; e Região Sul - estado do Paraná.

No ano de 2003 - de acordo com as informações transmitidas no seminário mencionado na página anterior - residiam no loteamento aproximadamente 5500 pessoas, das quais 2423 eram crianças, 3048 adultos e 89 gestantes (sendo que 14 pertenciam à faixa etária de 10 a 19 anos e 75 possuíam 20 anos ou mais).

De acordo com Piracicaba (2002b), a composição dessa população por faixa etária era: de 0 a 6 anos - 1389 (25,1\%), de 7 a 14 anos - 1094 (19,8\%), de 17 a 19 anos - 521 (9,4\%), de 20 a 39 anos - 1815 (32,8\%), de 40 a 59 anos - 592 (10,7\%) e de 60 anos ou mais - 120 (2,2\%). Observa-se que a população local é muito jovem, já que a faixa etária de 0 a 20 anos de idade representa quase $55 \%$ do total.

Uma característica marcante é a elevada rotatividade das famílias, o que dificulta o desenvolvimento de programas, segundo o relatório, já que a realidade local muda com freqüência. Há sempre pessoas novas chegando ao loteamento, de modo que não se sabe quem é realmente morador daquele local ou não. Além disso, há um intenso comércio de casas (Piracicaba, 2002b). Constatações como estas evidenciam o pouco, ou mesmo inexistente, vínculo entre a população e seu local de moradia e, também, entre os seus moradores.

Quanto à escolaridade, verifica-se que a grande maioria dos chefes de família não completou o primeiro grau e muitos deles não são alfabetizados. Há, ainda, muitas crianças fora da escola e a evasão escolar é bastante significativa.

O nível de renda da população é muito baixo: uma parcela relevante das famílias tinha rendimento inferior a três salários mínimos, havendo, também, 
muitos desempregados (em 2002, esse número chegava a 400). Além disso, o nível de formação profissional é quase inexistente (Piracicaba, 2002b).

\subsubsection{As moradias}

O Conjunto Habitacional consta de 1412 terrenos, dentre os quais 1370 são moradias e 42 destinados ao comércio. A área dos lotes é de aproximadamente $150 m^{2}$.

A moradia ou "embrião", como é denominada, tem $31,32 \mathrm{~m}^{2}$ de área construída e constitui-se de um quarto, cozinha e banheiro (Piracicaba, 2002b). Em conjunto, as moradias tornam a paisagem do loteamento extremamente monótona pois, além da arquitetura padronizada, há o predomínio da cor cinza do material construtivo.

Ao circular pelo local, facilmente verifica-se que poucos moradores tiveram condições financeiras ou desejo de "melhorar" a aparência das suas casas, conferindo-Ihes acabamento, pintura e plantas. A área externa de muitas ainda se encontra "na terra" e não raramente há presença de lixo e mato. Notam-se, também, a falta de calçadas e a existência de algumas poucas arvoretas.

$\mathrm{Na}$ Figura 7 , as fotografias $A, B$ e $C$ mostram o aspecto geral das moradias, enquanto na fotografia $D$ observa-se um pequeno jardim instalado fora da casa (em área de sistema de lazer), confirmando a utilização de áreas externas como extensão de suas próprias moradias.

Considerando-se que a população local vem aumentando (em 2001 eram 4.100 pessoas e ao final de 2003 esse número chegou a 5.500), questiona-se a qualidade de vida familiar da mesma, já que há apenas 1.370 moradias para abrigá-la. Como referem Heimstra \& McFarling (1978, p.46), a residência tem por objetivo "[...] prover abrigo físico para a família, lugares para as suas atividades e abrigo 
psicológico contra as pressões do mundo exterior". Entretanto, pelo que se observa nesse local, ela não só abriga e protege, mas também comprime. Essas constatações enfatizam a necessidade de áreas externas para a prática de diversas atividades que as moradias não comportam, entre as quais, os equipamentos públicos, priorizando-se os sistemas de lazer.
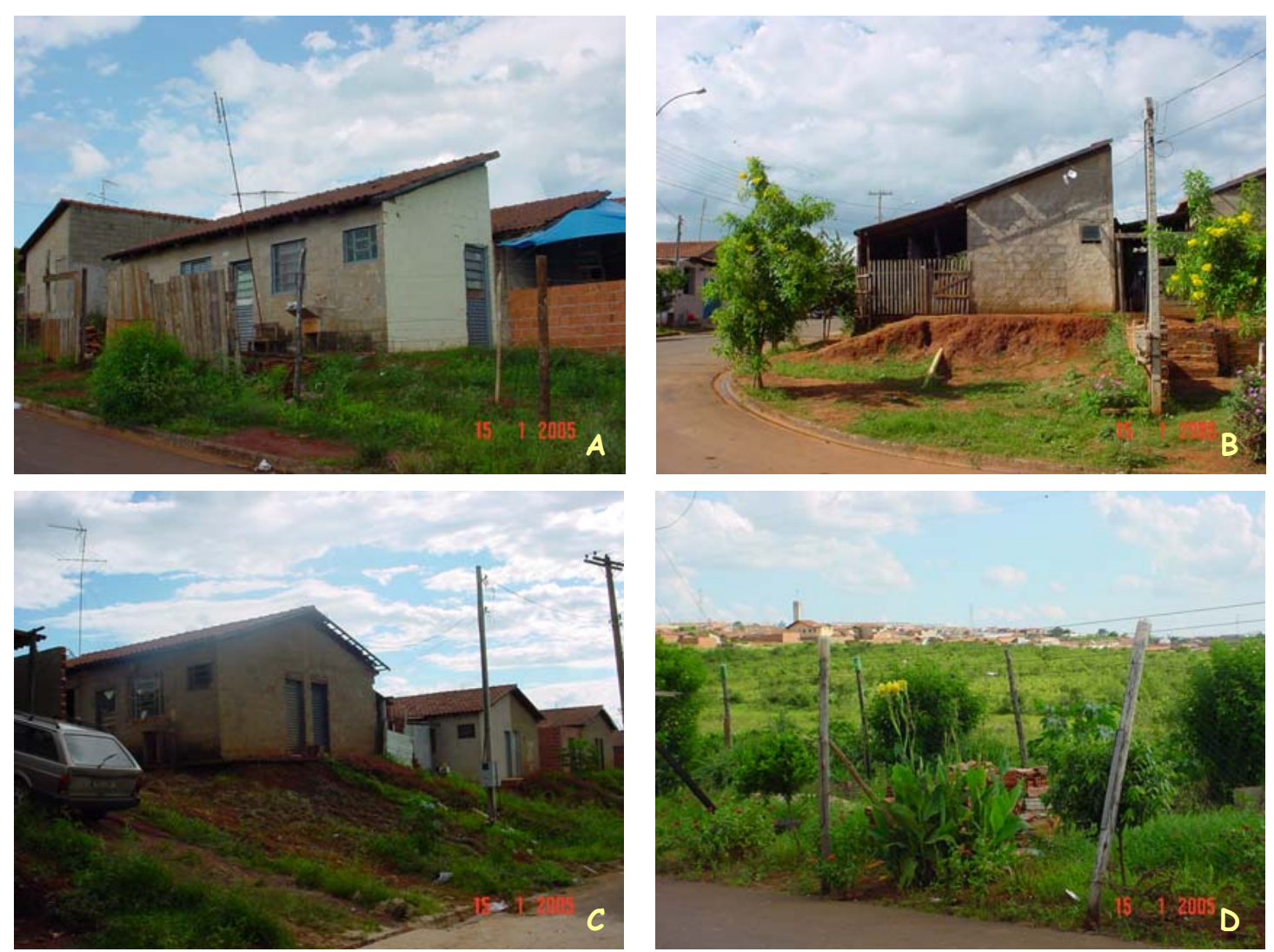

Figura 7 - A moradia ou "embrião do Bosques do Lenheiro Fonte: Fotografias tiradas pela autora

\subsubsection{Acesso a equipamentos públicos}

Constatou-se no Bosques do Lenheiro a existência de poucos equipamentos públicos a serviço da população, como: 
- 01 Escola Municipal (EMEF Prof. José Pousa de Toledo - pré-escola $/ 1^{a}$ a $4^{a}$ série), que atende 50 crianças na pré-escola e 585 crianças da $1^{a}$ a $4^{a}$ série. Devido à insuficiência de vagas, muitas crianças do loteamento são encaminhadas para escolas de bairros próximos ${ }^{20}$. Essa escola acolhe, ainda, duas classes com 87 alunos que participam do Programa de Alfabetização de Jovens e Adultos;

- 01 Escola Estadual (EE Dom Aniger Francisco de Maria Melillo - $5^{a}$ a $8^{a}$ série), que atende 422 crianças e adolescentes, em dois períodos (manhã/tarde). Há reivindicação, por parte da população, de que a escola passe a funcionar também no período noturno, para que a demanda dos jovens do loteamento seja atendida;

- 02 equipes do Programa de Saúde da Família (PSF): atuam preventivamente na saúde, visitando todas as famílias do bairro;

- 01 Posto da Guarda Municipal: zela pela segurança do bairro e auxilia o público:

- 01 escritório de serviço social da Secretaria Municipal de Desenvolvimento Social (SEMDES), que conta 1 assistente social e 1 estagiário;

- 1 escritório de serviço social da Empresa Municipal de Desenvolvimento Habitacional (EMDHAP), que conta 1 assistente social e 1 estagiário. Seu objetivo é despertar na população a fixação das famílias no bairro e proporcionar garantia de moradia;

- 01 casa para atividades gerais, que atualmente é utilizada para aulas de curso de panificação.

O Conjunto Habitacional também possui transporte público municipal.

Em reuniões do comitê local (organizado por ocasião das discussões sobre a "Proposta para a Jornada da Cidadania", anteriormente mencionada), constatou-se

${ }^{20}$ Segundo a SEMDES, a escola do Godinhos atende 5 crianças na pré-escola e 106 da $1^{a}$ a $4^{a}$ série; a escola de Vila Fátima atende 58 crianças na pré-escola; a escola Dona Mimi atende 50 crianças na pré-escola. 
que a principal reivindicação da Comissão de Mães do Bosques é a construção de creche para as crianças, possibilitando-Ihes trabalhar fora. O número de crianças é muito grande e as dimensões do terreno, necessárias para a construção da creche, não são compatíveis com as áreas reservadas para equipamentos públicos do loteamento, sendo necessário buscar, nas imediações, terrenos que possam ser utilizados para essa finalidade. Optou-se por destinar uma área reservada para sistema de lazer, proposta que não foi aceita pelas mães.

Tal fato constitui elemento bastante significativo neste estudo, pois outra reivindicação que fazem é por lazer para as crianças e pelo embelezamento do bairro. Algumas das mães chegam até a idealizar como seria um desses sistemas de lazer implantado, propondo que a frente de trabalho existente no local, ociosa no momento do levantamento de dados, pudesse ser utilizada para tal, além de construir a creche pretendida, desde que o material fosse doado pela Prefeitura.

\subsubsection{Sistemas de lazer do loteamento}

Analisando-se o mapa das áreas públicas destinadas para sistemas de lazer e institucional do Bairro Mário Dedini, identificou-se a existência de 10 sistemas de lazer no loteamento Bosques do Lenheiro, totalizando $62.816,70 \mathrm{~m}^{2}$. Destes, 7 $\left(26.303,47 m^{2}\right)$ são classificados como não implantados e $3\left(36.513,23 m^{2}\right)$ como non-aedificandi (nota-se que a classificação compreende as opções: implantado, não implantado, ocupado por equipamento público, ocupado por favela, ocupado por outros, non-aedificandi e em A.P.P., conforme a Anexo A). A identificação, a área em metros quadrados e a classificação dos sistemas de lazer, segundo critério da Prefeitura do Município de Piracicaba, são apresentados na Tabela 6. 
Tabela 6. Sistemas de lazer do loteamento Bosques do Lenheiro, com identificação, classificação e metragem

\begin{tabular}{|c|c|c|}
\hline Identificação & Classificação dos Sistemas de Lazer & Área $\left(m^{2}\right)$ \\
\hline XVI.2.1 & não implantado & $5.412,00$ \\
\hline XVI.2.2 & não implantado & $4.498,32$ \\
\hline XVI.2.3 & não implantado & $1.125,15$ \\
\hline XVI.2.4 & não implantado & $1.310,00$ \\
\hline XVI.2.5 & não implantado & $1.810,00$ \\
\hline XVI.2.6 & não implantado & $7.927,00$ \\
\hline \multirow[t]{2}{*}{ XVI.2.7 } & não implantado & $4.221,00$ \\
\hline & Total não implantado $\left(m^{2}\right)$ & $26.303,47$ \\
\hline XVI.2.15 & non-aedificandi & $6.268,71$ \\
\hline XVI.2.16 & non-aedificandi & $24.557,50$ \\
\hline \multirow[t]{3}{*}{ XVI.2.17 } & non-aedificandi & $5.687,02$ \\
\hline & Total non-aedificandi $\left(m^{2}\right)$ & $36.513,23$ \\
\hline & Total $\left(m^{2}\right)$ & $62.816,70$ \\
\hline
\end{tabular}

Fonte: Piracicaba (2004)

Embora o material de análise não forneça maior detalhamento sobre a classificação utilizada, nota-se que não há sistemas de lazer implantados, o que equivale a dizer que nenhum daqueles identificados no loteamento recebeu o tratamento considerado adequado pela Prefeitura, de modo a cumprir com as suas finalidades precípuas.

Em campo, verificou-se que todas as 10 áreas públicas destinadas a sistemas de lazer estão abandonadas. Nesse sentido, o presente estudo vem ao encontro dos resultados obtidos por Geraldo (1997), nas cidades de Bariri, Brotas e Dois Córregos, interior do estado de São Paulo, onde nem todos os espaços públicos relacionados pelas prefeituras estavam efetivamente implantados, existindo, apenas, a área física, sem equipamentos ou vegetação, principalmente aqueles localizados nas regiões de expansão mais recente ou em conjuntos habitacionais.

A Figura 8 mostra a situação atual de alguns sistemas de lazer não implantados do loteamento. Na fotografia $A$, observa-se o sistema de lazer 
identificado como XVI.2.1, na Tabela 6 , com construção e quadra não concluídos que, mesmo nessa situação, são bastante utilizados pelos jovens. A fotografia $B$ mostra o sistema XVI.2.2 com acúmulo de lixo e entulho. Pode-se notar, à esquerda na fotografia $C$, uma sequiência desses sistemas de lazer ao longo da rua (XVI.2.5, XVI.2.4, XVI.2.3, XVI.2.6), totalmente abandonados, enquanto a fotografia $D$ mostra o sistema XVI.2.5, onde a população "adapta" condições para o desempenho do lazer. Logo atrás deste último, situa-se mais um sistema (XVI.2.7) que não possui a mínima condição de uso.
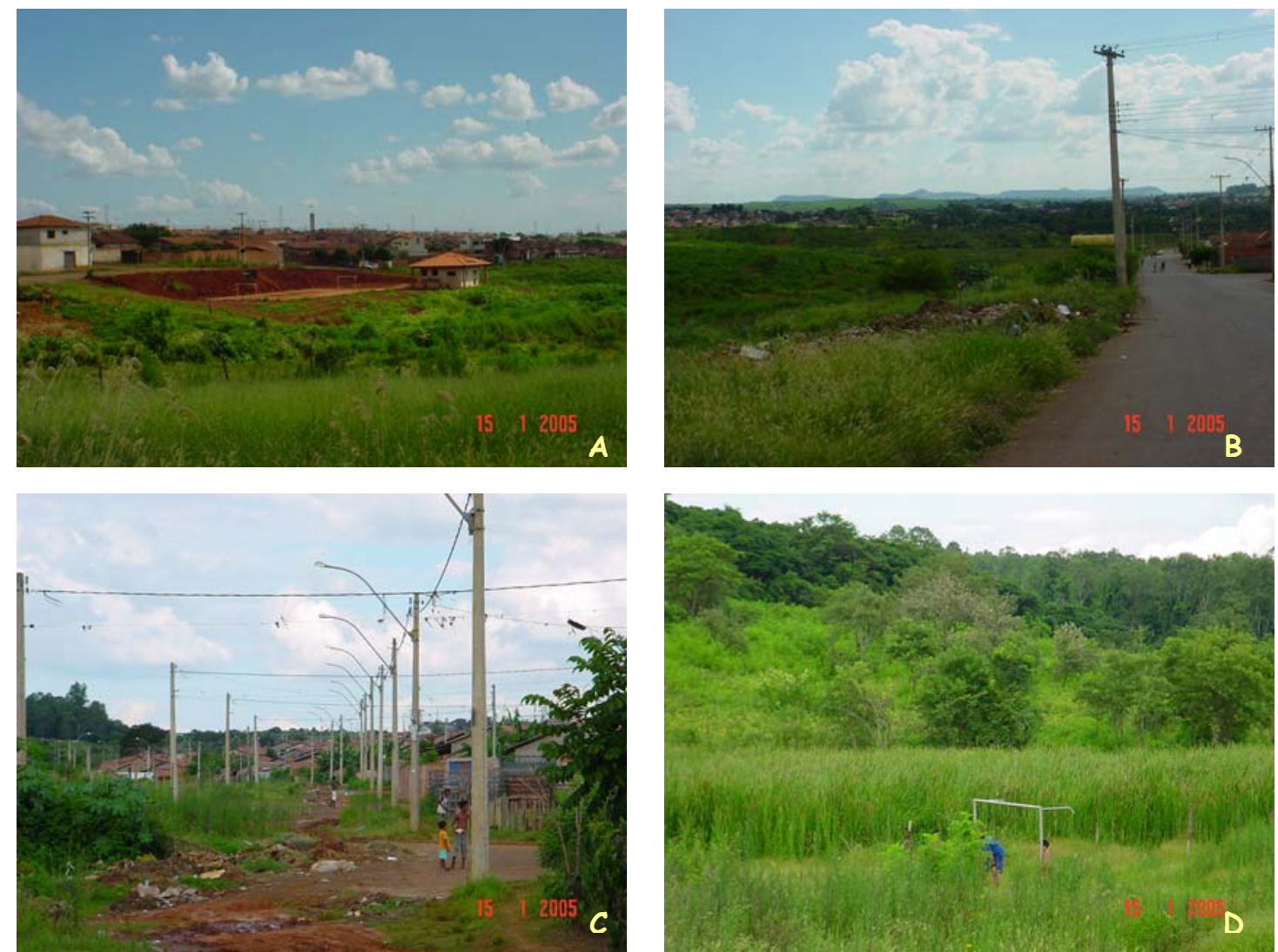

Figura 8 - Situação atual dos sistemas de lazer do loteamento Fonte: Fotografias tiradas pela autora

A classificação non-aedificandi refere-se às áreas sob linhas de alta tensão, enquadradas como faixas de domínio ou faixas de servidão da companhia energética 
local, a qual deve ser previamente consultada com vistas à aprovação para utilização. Por se tratar de área de segurança e oferecer risco às pessoas, definitivamente não deveriam ser designadas ao lazer da população. Se, por este motivo, fossem subtraídas do cômputo total de sistemas de lazer, a situação se tornaria ainda mais crítica no loteamento, pois são as maiores áreas destinadas a esse fim.

Levando-se em conta a restrição na utilização, e também que as áreas estão abandonadas, vale retomar a já referida menção de Cavalheiro (1982) acerca de experiências estrangeiras de utilizar espaços livres públicos para hortas comunitárias. No município de Piracicaba, encontra-se em andamento o programa municipal "Horta Domiciliar", que visa à geração de renda para famílias carentes, em bairros da periferia, inclusive no Bosques do Lenheiro. Sem dúvida alguma, trata-se de uma iniciativa louvável por possibilitar o abastecimento das famílias mas, utópica quanto à geração de renda em âmbito domiciliar, a começar pelas infimas dimensões dos lotes nesses loteamentos populares.

Ainda, na sequiência, a dependência do poder público no fornecimento de insumos, instrução técnica e sua continuidade, através das gestões administrativas, teriam grande importância na sobrevivência e sucesso do programa. Talvez, uma tentativa em sua viabilização seja fomentá-lo, no âmbito de cooperação entre famílias, tornando o quadro mais otimista, aventando possibilidade de utilização desses sistemas de lazer non-aedificandi especificamente para esse loteamento ou outros em que a situação seja semelhante.

Acredita-se que uma iniciativa nesse sentido possa dar certo, principalmente por verificar em campo que, timidamente, a população do bairro passa a se apropriar de partes dessas áreas para cultivar mandioca, milho, flores, hortaliças, entre outros, embora a área seja também utilizada para outros fins, desde abrigo e 
pastejo de animais até depósito de lixo e entulho, periodicamente recolhidos pela Prefeitura.

A situação atual de alguns dos sistemas de lazer non-aedificandi pode ser observada na Figura 9. Nota-se, na fotografia A, o sistema de lazer identificado como XVI.2.16, na Tabela 6, com alguns canteiros de hortaliças $e$, na fotografia $B, 0$ plantio de algumas plantas ornamentais, sob fios de alta tenção. Já na fotografia $C$, um sistema (XVI.2.16) utilizado para o abrigo e pastejo de animais.
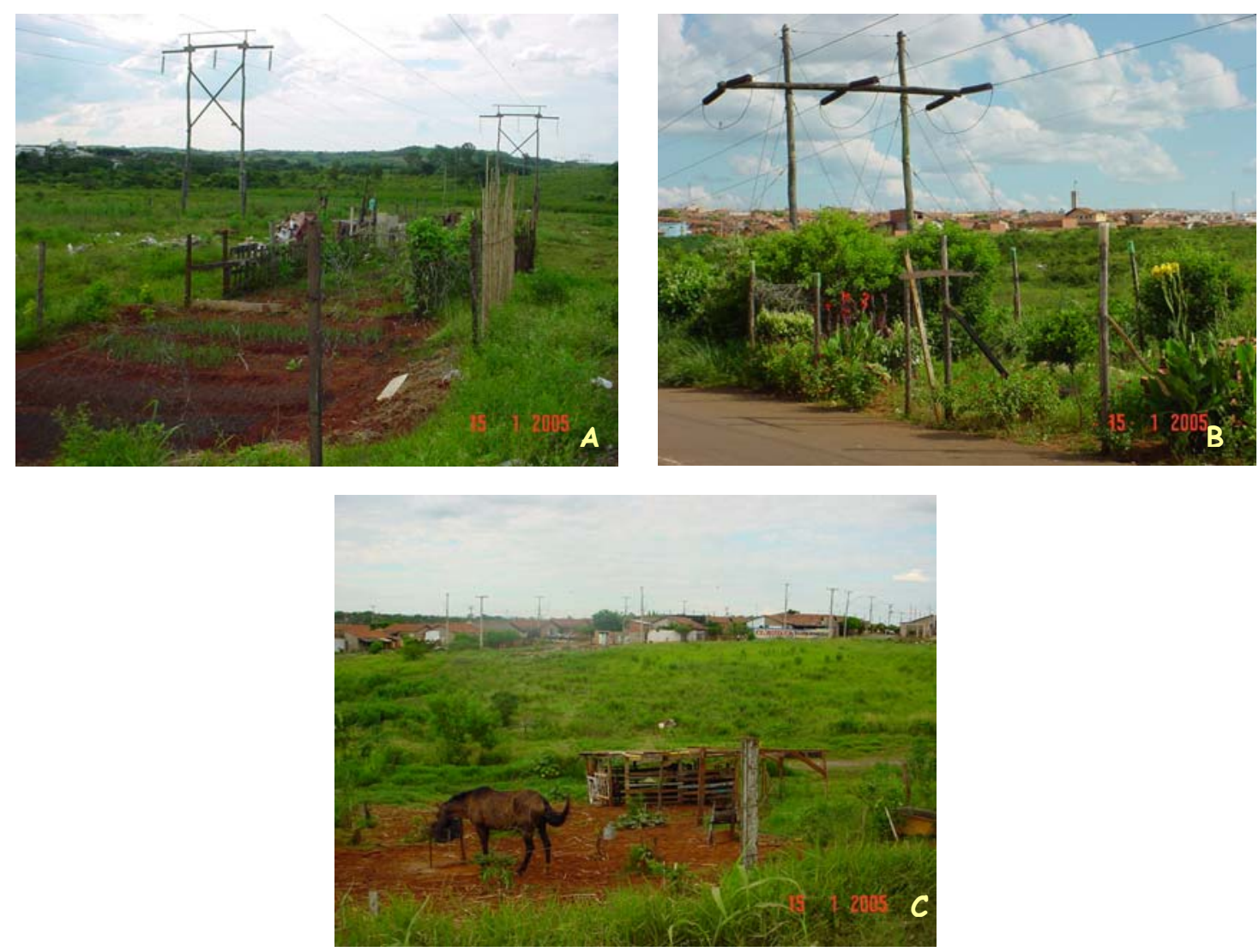

Figura 9 - Situação atual dos sistemas de lazer non-aedificandi do loteamento Fonte: Fotografias tiradas pela autora

Diferentemente do que ocorre com as escolas do Bosques, que por não oferecerem vagas suficientes para suas crianças $e$ adolescentes acabam por 
encaminhá-los às escolas de bairros próximos, a falta de sistemas de lazer implantados não pode ser suprida nas redondezas. Observando-se o Bairro Mário Dedini (Anexo A), composto pelos loteamentos Mário Dedini e Bosques do Lenheiro, este fato torna-se evidente.

A esse respeito, observou-se que a Prefeitura tem tomado alguma iniciativa como forma de compensar essa carência por lazer gratuito, como a abertura das escolas municipal e estadual aos finais de semana, baseada na tese de que uma boa proposta pedagógica, aliada a atividades culturais, esportivas e de lazer, pode estimular a frequiência e colaborar para a redução da evasão escolar existente no local. Além de possibilitarem o uso das quadras esportivas, principalmente pelas crianças e adolescentes, propiciam também atividades como aulas de dança de rua, coral, capoeira, catecismo, entre outras.

Embora, nos últimos anos, as escolas tenham sido eleitas para desempenhar um importante papel comunitário, há que se ressaltar que os equipamentos públicos voltados ao lazer também são essenciais $e$, sob qualquer hipótese, podem ser preteridos, na justificativa de essas escolas estarem contemplando o lazer necessário à população.

Mas, se às escolas é atribuída a função de compensar a falta de opções de lazer e, de certa forma, propiciar o convívio social, como poderia ser compensada a falta de vegetação que deve estar presente num sistema de lazer? Apresenta-se tal indagação por se perceber que não houve muita preocupação do poder público local nesse sentido, já que os sistemas de lazer existem e não receberam nenhum tratamento.

Os custos de implantação e, principalmente de manutenção, são geralmente apontados como o principal entrave para a tomada de atitude, de maneira que esses espaços são deixados ao abandono, sem possibilidade alguma de exercerem suas principais funções (ecológica, estética e social), estendendo seus benefícios à 
melhoria na qualidade de vida familiar e comunitária. Por outro lado, trata-se de um local de adensamento populacional considerável, questionando-se, inclusive, no caso de estes espaços estarem prontamente disponíveis à população, se permitiriam um lazer saudável a todos.

Ainda, sem se deter a uma metodologia específica de cálculo, verifica-se que os $26.303,47 \mathrm{~m}^{2}$ referentes aos sistemas de lazer não implantados, aqueles que efetivamente poderiam ser utilizados para fins de lazer, quando divididos pela população residente do Conjunto Habitacional, de aproximadamente 5.500 pessoas, teriam como resultado $4,8 \mathrm{~m}^{2}$ /habitante, valor bem abaixo do estabelecido pela Lei Orgânica do Município de $10 \mathrm{~m}^{2} /$ habitante, em toda a cidade, sem distinção entre bairros.

Mesmo que não fosse possível incluir no projeto dos espaços públicos de lazer ao ar livre uma variedade de equipamentos que oneram o seu custo, seria muito importante que fossem dotados, pelo menos, de vegetação. Dos benefícios ambientais proporcionados pelas árvores, a melhoria do conforto térmico, para esse local, seria preponderante. Ainda, oportunizariam o lazer, quer pela contemplação de paisagem quer por um simples descanso ou conversa sob a sombra de suas árvores, ou, talvez, poderiam ainda enriquecer atividades lúdicas e educativas, principalmente das crianças.

Conferir cor e beleza, a partir de seus atributos intrínsecos e, também, pela diversidade de elementos, além de sabores e aromas, estímulos à sensibilidade contra a crueza da vida cotidiana enfrentada pela população local, no mínimo, seria de grande valia.

Outro fato constatado foi que a maior parte dos sistemas de lazer do loteamento está associada a áreas de preservação permanente, também sem a devida atenção (nota-se que no Anexo $A$ as nascentes e cursos d'água estão representados por linhas azuis). A Figura 10 exemplifica a área de preservação 
permanente existente entre os sistemas de lazer não implantados XVI.2.1 e XVI.2.2 (situado mais à frente na fotografia), identificados conforme Tabela 6.

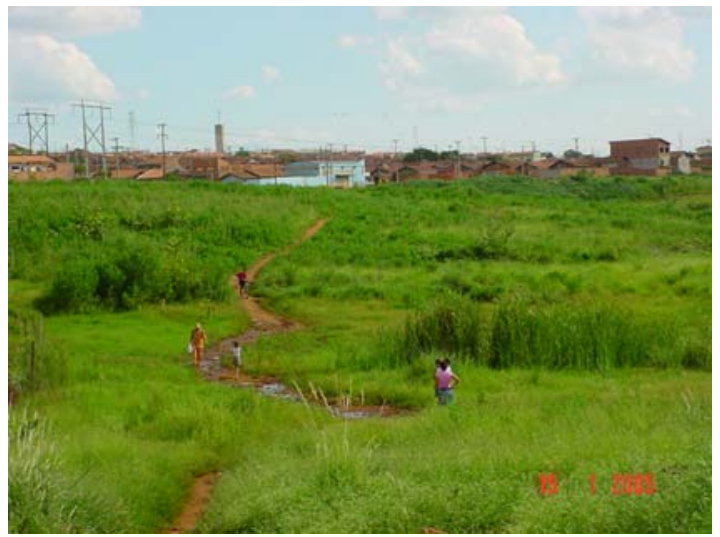

Figura 10 - Área de preservação permanente presente entre sistemas de lazer não implantados

Fonte: Fotografias tiradas pela autora

Embora a avaliação da arborização de ruas não faça parte da proposta desse estudo, notou-se que ela é praticamente inexistente, até porque a maior parte das casas ainda não possui calçadas. Nesse sentido, em parecer técnico sobre aspectos relacionados a impacto ambiental e condições de risco, constatou-se que, no Conjunto Habitacional Bosques do Lenheiro, há uma área com acúmulo superficial (sazonal) de águas pluviais que não torna aquela porção do loteamento proibitiva para a ocupação por residências, sendo necessárias, porém, "[...] algumas medidas corretivas simples e não onerosas [...]", dentre as quais, a "[...] execução do projeto de arborização (ruas e APP) em sintonia com estas características do terreno (espécies adequadas ao tipo de solo)" (Cerri \& Zaine, 1999, p. 6).

Percebeu-se, também, que na rua principal do Conjunto Habitacional, onde estão situadas as duas escolas e por onde passa o transporte público municipal, há um grande volume de pessoas circulando, principalmente crianças que não se acanham em injuriar as raras mudas plantadas nas calçadas que, em pouco tempo, tornam-se uma sequiência de "tocos". Vê-se que, se por uma lado a Comissão de 
Mães do Bosques reivindica ações quanto à implantação dos sistemas de lazer, por outro, parece haver necessidade de valorização do bem público, ou daquele que pertence à coletividade, fazendo-se necessário que tais ações não sejam efetuadas sem um processo educacional. 


\section{CONCLUSÃO}

- O Conjunto Habitacional Bosques do Lenheiro foi definido como a área "mais violenta" do município de Piracicaba, por ser o local de maior procedência de crianças e adolescentes em situação de rua (34,5\% do total analisado) e de jovens infratores em cumprimento de medidas socioeducativas da Liberdade Assistida e da Prestação de Serviços à Comunidade ( $9,2 \%$ do total analisado);

- Pertencente ao Bairro Mário Dedini, o Conjunto Habitacional Bosques do Lenheiro é um loteamento de interesse social, localizado na Região Norte do município, e tido como o mais pobre. São 1370 moradias, aproximadamente 5500 habitantes, sendo a população muito jovem (a faixa etária de 0 a 20 anos de idade representa quase $55 \%$ do total);

- Não há sistemas de lazer implantados no loteamento, disponíveis ao uso dos moradores. Nenhuma das dez áreas públicas destinadas a esse fim recebeu algum tipo de tratamento pela Prefeitura e estão abandonadas. Da totalidade $\left(62.816,70 \mathrm{~m}^{2}\right), 3$ áreas se classificam como non-aedificandi $\left(36.513,23 \mathrm{~m}^{2}\right)$, sob linhas de alta tensão que, por serem áreas de segurança da companhia energética local e oferecerem risco às pessoas, definitivamente não deveriam ser designadas ao lazer:

- De maneira geral, a situação da arborização no local é crítica: sem sistemas de lazer, ela inexiste e o plantio das áreas de preservação permanente, associadas a esses sistemas, ainda não foi implementado. Embora sua avaliação não faça parte 
da proposta deste estudo, a arborização de ruas é praticamente inexistente, pois a maior parte das casas nem mesmo possui calçadas;

- O grande volume de literatura consultada aponta para uma relação realmente consistente entre arborização, lazer e redução da violência, não só em países do Hemisfério Norte, como no Brasil. Embora a oferta de arborização e lazer represente apenas uma pequena parcela das carências observadas na área de estudo, a implantação desses sistemas pode contribuir para que ela se torne, ambiental e socialmente, um local melhor para se viver, pois valorizar o local é valorizar o próprio homem.

\subsection{Considerações finais}

Algumas contribuições relevantes podem ser estabelecidas a partir dos resultados obtidos neste estudo.

Uma primeira evidência, tirada a partir das estatísticas observadas no município de Piracicaba, é que, a despeito de a literatura se concentrar no estudo da violência e suas causas nos grandes centros urbanos, essa é a realidade também nas cidades de médio porte, como aqui apresentado, exigindo uma ampla discussão da urgência do poder público, através de suas diversas esferas, em investir preventivamente na questão.

Um outro elemento de destaque refere-se à coincidência da área estudada em reunir os maiores índices de violência, envolvendo crianças e adolescentes, ora vítimas, ora agentes. Tal constatação reforça que ali estão reunidas características socioambientais que levam a uma situação precária de sociabilidade.

O fato de a área caracterizada como "a mais violenta" do município ser um local "dito" planejado, tornou-se um terceiro elemento de grande relevância captado por este estudo. Não basta a intervenção do setor público: ela tem que ter 
qualidade. Sob esse aspecto, os sistemas de lazer devem ser implantados e, além de propiciar oportunidades de lazer, cumprir com as suas funções ecológica e estética.

Casas chamadas "embriões", padronizadas, congestionadas numa área praticamente destituída de arborização, em que o cinza predomina, parecem constituir ambientes que, de fato, propiciam insatisfação com a própria vida $e$ sensação de desamparo social que conduzem à violência.

Com base nas observações, pode ser sugerido, a curto e médio prazo, aproveitar a Comissão de Mães do local, reunindo frentes de trabalho dispostas a se envolver na elaboração, execução e manutenção dos sistemas de lazer do local, buscando parceria que possa fornecer material e orientação técnica.

De grande preocupação reveste-se o fato verificado de que muitas das crianças e adolescentes envolvidos com a violência no município são provenientes de loteamentos semelhantes ao avaliado neste estudo, do que decorre a necessidade de se desenvolverem mais trabalhos visando a ações preventivas, específicas para cada local.

Dada a profundidade e a multidisciplinaridade do assunto, é importante salientar que, no que se refere ao paisagismo, medidas simples, mas eficientes, muitas vezes munidas mais de boa vontade do que de técnicas, podem começar a mudar esse quadro - e estudos já vêm comprovando isso. O lazer no planejamento urbano, como direito de qualquer cidadão, princípio do urbanismo, já proposto na Carta de Atenas (Le Corbusier, 1989), além de exigido por lei em todo loteamento urbano, se contemplado a contento, pode ser o início na reversão de muitos dos processos de desvios da sociedade mais jovem. 
ANEXOS 
ANEXO A. Diagnóstico das áreas públicas destinadas para sistemas de lazer e institucional - Dados do Bairro Mário Dedini (escala 1:10.000). Fonte: Adaptado de Piracicaba (2004). 


\section{MARIO DEDINI (XVI)}

$95,96 \%$

SISTEMA DE LAZER (10,25ha)

ENTOS COM SISTEMAS DE LAZER CONFORME NUMERAÇÃO MÁRIO DEDINI

XVI.2 = BOSQUE DOS LENHEIROS

UADRO DE ÁREAS $\left(\mathrm{m}^{2}\right)$ CONFORME NUMERAÇÃO

\begin{tabular}{|c|c|c|}
\hline $207,15 \mathrm{~m}^{2}$ & $\square$ & ${ }^{*}$ XVI.1.19 = 1.910,00m² \\
\hline $155,62 m^{2}$ & $\square$ & ${ }^{*}$ XVI.1.20 = 1.180,00m² \\
\hline $943,65 m^{2}$ & $\square$ & XVI.2.1 = 5.412,00 $\mathrm{m}^{2}$ \\
\hline $390,00 \mathrm{~m}^{2}$ & $\square$ & XVI.2.2 = 4.498,32m² \\
\hline $392,24 m^{2}$ & $\square$ & XVI.2.3 $=1.125,15 \mathrm{~m}^{2}$ \\
\hline $.893,65 \mathrm{~m}^{2}$ & $\square$ & XVI.2.4 $=1.310,00 \mathrm{~m}^{2}$ \\
\hline $30,96 m^{2}$ & $\square$ & XVI.2.5 $=1.810,00 \mathrm{~m}^{2}$ \\
\hline $61,74 \mathrm{~m}^{2}$ & $\square$ & XVI.2.6 $=7.927,00 \mathrm{~m}^{2}$ \\
\hline $710,00 \mathrm{~m}^{2}$ & $\square$ & XVI.2.7 $=4.221,00 \mathrm{~m}^{2}$ \\
\hline $80,15 \mathrm{~m}^{2}$ & $\square$ & XVI.2.8 = $2.706,78 \mathrm{~m}^{2}$ \\
\hline $80,46 m^{2}$ & $\square$ & XVI.2.9 $=10.054,24 \mathrm{~m}^{2}$ \\
\hline $4,00 m^{2}$ & $\square$ & XVI.2.10 = 6.309,34m² \\
\hline $379,00 \mathrm{~m}^{2}$ & $\square$ & XVI.2.11 = 6.309,34m² \\
\hline $40,00 \mathrm{~m}^{2}$ & $\square$ & XVI.2.12 = 2.594,15m² \\
\hline $0,00 \mathrm{~m}^{2}$ & $\square$ & XVI.2.13 = $1.139,52 \mathrm{~m}^{2}$ \\
\hline $0,00 \mathrm{~m}^{2}$ & $\square$ & XVI.2.14 = 3.619,16m² \\
\hline $0,00 m^{2}$ & $\square$ & XVI.2.15 = 6.268,71 $\mathrm{m}^{2}$ \\
\hline $0,00 m^{2}$ & $\square$ & XVI.2.16 = 24.557,50 $\mathrm{m}^{2}$ \\
\hline & & XVI.2.17 = 5.687,02 $\mathrm{m}^{2}$ \\
\hline
\end{tabular}

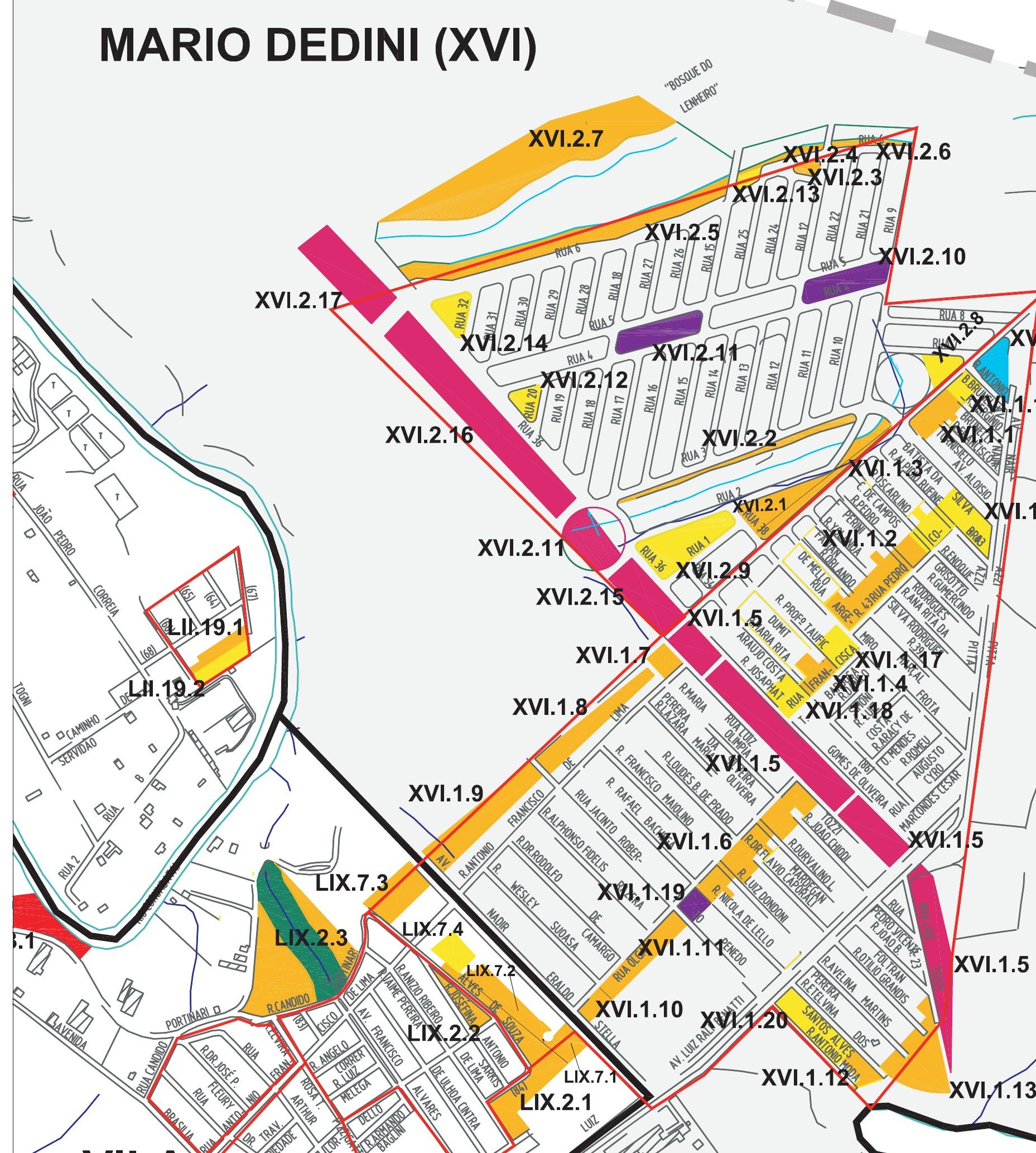


ANEXO B. Procedência das crianças e adolescentes em situação de rua. Fonte: CRAMI (2002).

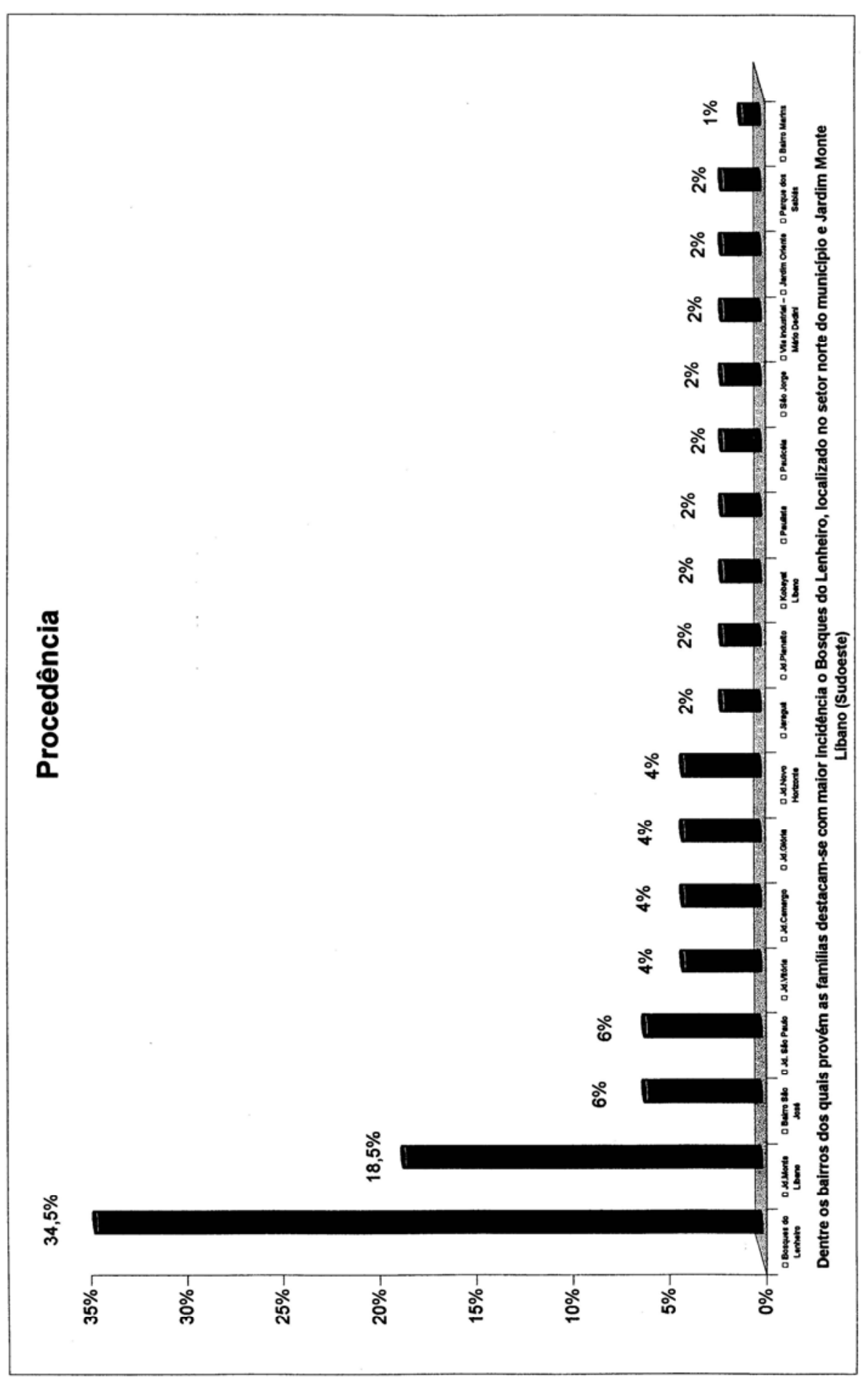


ANEXO C. Situação habitacional das crianças e adolescentes em situação de rua. Fonte: CRAMI (2002).

픈

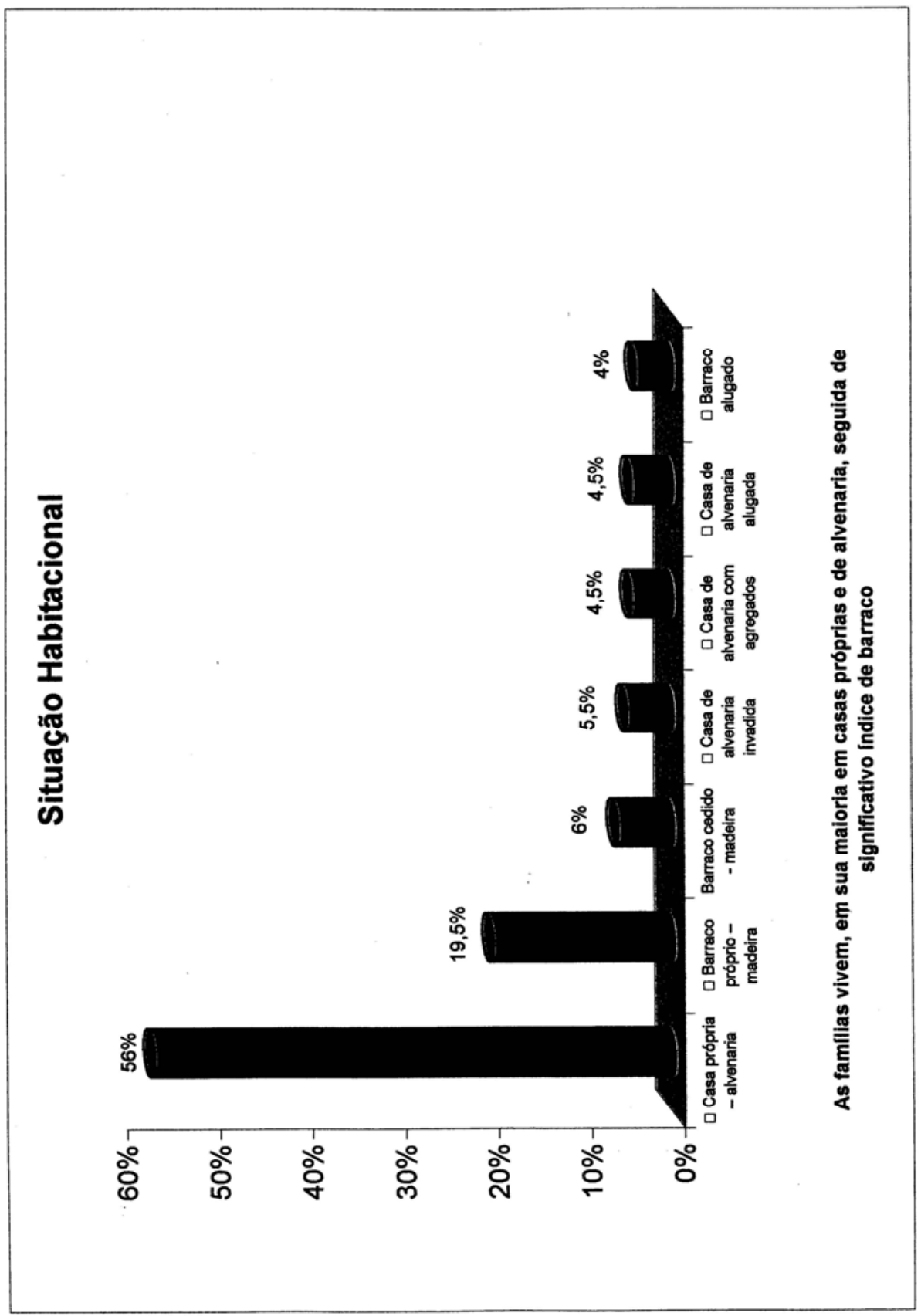


68

ANEXO D. Situação familiar das crianças e adolescentes em situação de rua.

Fonte: CRAMI (2002).

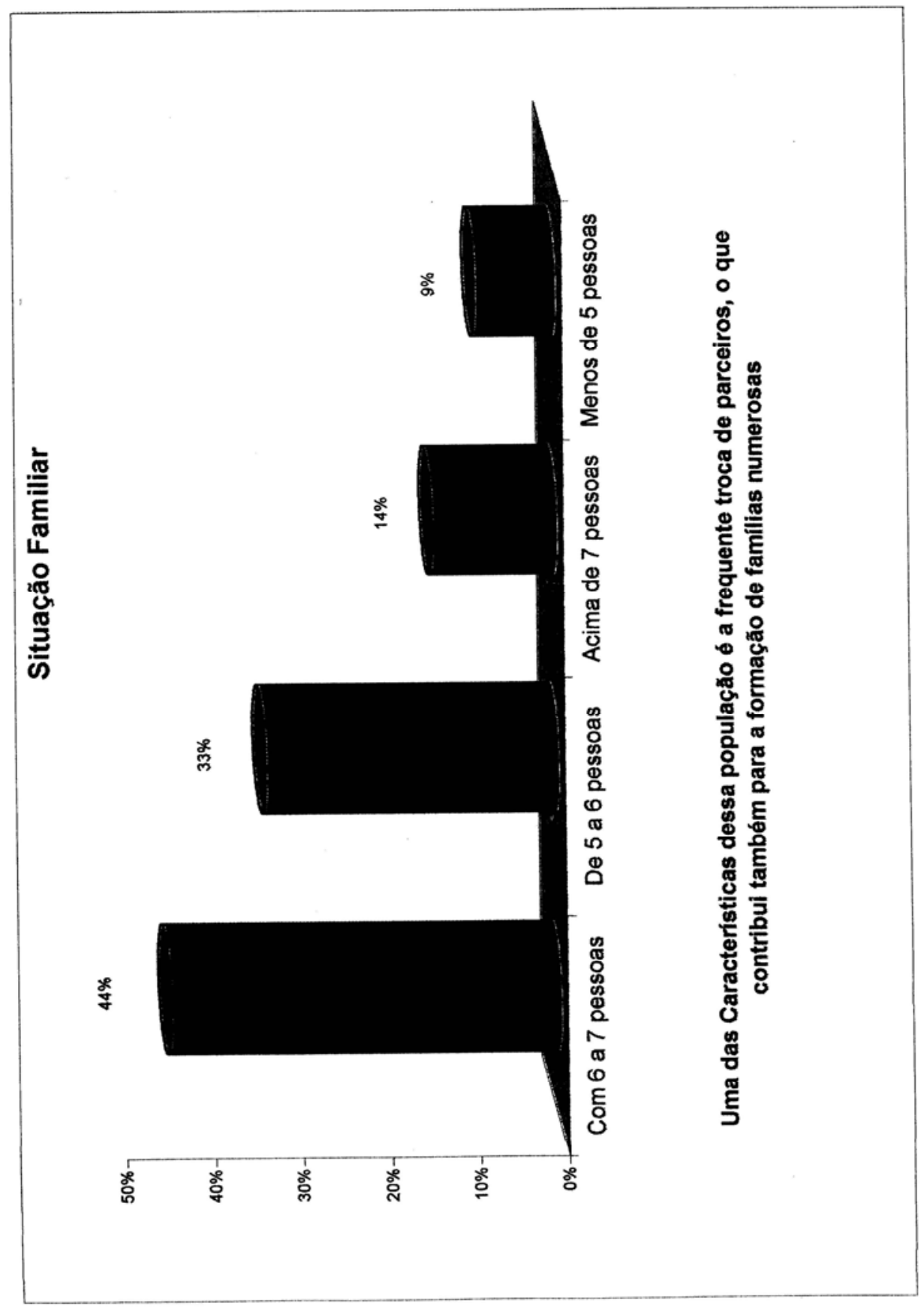


ANEXO E. Renda familiar das crianças e adolescentes em situação de rua.

Fonte: CRAMI (2002).

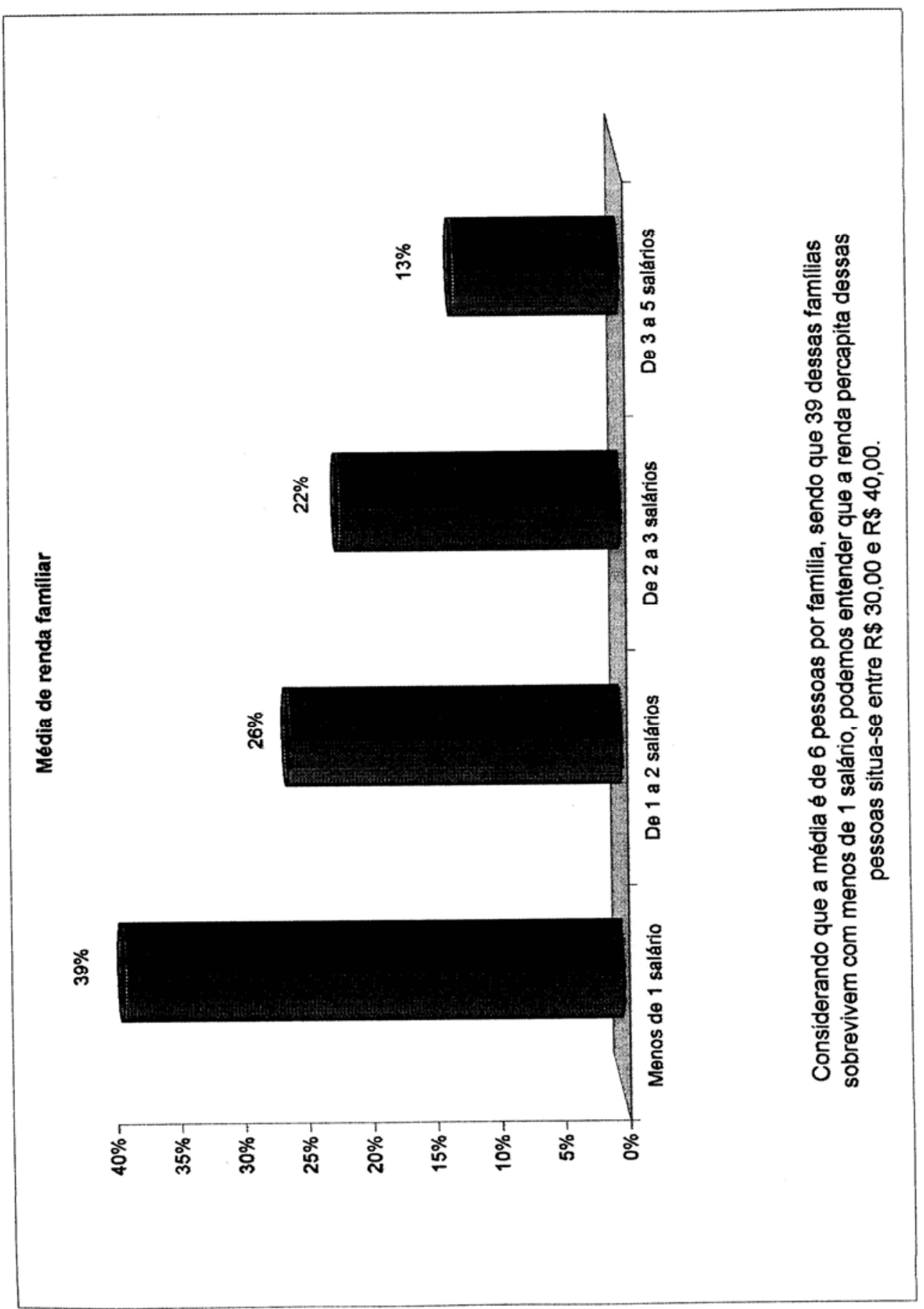




\section{REFERÊNCIAS BIBLIOGRÁFICAS}

ADORNO, R.C.F. Apontamentos sobre qualidade de vida, lazer e violência. Debates Sócio-Ambientais, v.3, n. 9, p.13-14, 1998.

ADORNO, S. Precocious delinquency: young people and gangs in São Paulo (Brazil). Chicago, USA: American Anthropological Association, 1998. 13 p.

BRASIL, Leis, Decretos, etc. Lei $n^{\circ}$ 8.069, de 13 de julho de 1990. Estatuto da criança e do adolescente. http://www.presidencia.gov.br/sedh (7 Dez. 2004)

CALDEIRA,T.P.R. Cidade de muros: crime, segregação e cidadania em São Paulo. São Paulo: Editora 34/EDUSP, 2000. 400 p.

CARDIA, N. A violência urbana e os jovens. In: PINHEIRO, P.S. São Paulo sem medo: um diagnóstico da violência urbana. São Paulo: Garamond, 1998. 254p.

CARDIA, N.; SHIFFER, S.R. Urbanization, youth and risk factors for substance abuse: São Paulo secondary data analysis. São Paulo: World Health Organization, 2000. (Relatório de pesquisa)

CARVALHO, L.M. Áreas verdes da cidade de Lavras/MG: caracterização, usos e necessidades. Lavras, 2001. 115p. Dissertação (Mestrado) - Universidade Federal de Lavras 
CASTRO, G.C. (coord.); ABRAMOVAY, M.; RUA, M.G.; ANDRADE, E.R. Cultivando vida, desarmando violências: experiências em educação, cultura, lazer, esporte e cidadania com jovens em situações de pobreza. Brasília: UNESCO/Brasil Telecom, Fundação Kellogg, Banco Interamericano de Desenvolvimento, 2001. $583 p$.

CAVALHEIRO, F. O planejamento de espaços livres: o caso de São Paulo. In: CONGRESSO NACIONAL SOBRE ESSÊNCIAS NATIVAS, Campos do Jordão, 1982. Anais. São Paulo: Silvicultura em São Paulo, 1982. p.1819-1831.

CAVALHEIRO, F.; NUCCI, J.C; GUZZO, P.; ROCHA, Y.T. Proposição de terminologia para o verde urbano. Boletim Informativo da SBAU (Sociedade Brasileira de Arborização Urbana), v.7, n.3, p.7, jul/ago/set de 1999.

CENTRO REGIONAL DE REGISTROS E ATENÇÃO AOS MAUS TRATOS NA INFÂNCIA DE PIRACICABA. Projeto "acolhimento à criança e ao adolescente em situação de rua". Piracicaba, 2002. 11p.

CERRI, L.E.S.; ZAINE, J.E. Parecer técnico sobre situações de risco e caracterização geológico-geotécnica de área de reassentamento urbano. Rio Claro: IGCE/UNESP, Depto. Geologia Aplicada, 1999. 7p. (Parecer técnico apresentado à Empresa Municipal de Desenvolvimento Habitacional de Piracicaba (SP) - EMDHAP).

DE ANGELIS, B.L.D. A praça no contexto das cidades. O caso de Maringá. São Paulo, 2000. 356p. Tese (Doutorado) - Faculdade de Filosofia, Letras e Ciências Humanas, Universidade de São Paulo.

DESLANDES, S.F. Prevenir a violência: um desafio para profissionais de saúde. Rio de Janeiro: FIOCRUZ/ENSP/CLAVES, 1994. 40p. 
GERALDO, J.C. A evolução dos espaços livres públicos de Bariri, Brotas e Dois Córregos-SP. São Paulo, 1997. 209p. Dissertação (Mestrado) - Faculdade de Filosofia, Letras e Ciências Humanas, Universidade de São Paulo.

GUZZO, P. Estudo dos espaços livres de uso público da cidade de Ribeirão Preto com detalhamento da cobertura vegetal e áreas verdes públicas de dois setores urbanos. Rio Claro, 1999. 125p. Dissertação (Mestrado) - Instituto de Biociências, Universidade Estadual Paulista "Júlio de Mesquita Filho".

HEIMSTRA, N,W.; MCFARLING, L. H. Psicologia ambiental. São Paulo: EPU/EDUSP, 1978. 218 p.

htm (10 Set. 2004).

KUO, F.E.; BACAICOA, M.; SULLIVAN, W.C. Transforming inner-city landscapes: trees, sense of safety, and preference. Environment and Behavior. v.30, n.1, p.28-59, Jan. 1998a.

KUO, F.E.; SULLIVAN, W.C.; COLEY, R.L.; BRUNSON, L. Fertile ground for community: inner-city neighborhood commom spaces. American Journal of Community Psychology. v.26, n.6, p.823-851, Dec. 1998b.

LE CORBUSIER. A carta de Atenas. São Paulo: HUCITEC/EDUSP, 1989.

LIMA, A.M.L.P. Análise da arborização viária na área central e em seu entorno. Piracicaba, 1993. 238 p. Tese (Doutorado) - Escola Superior de Agricultura "Luiz de Queiroz", Universidade de São Paulo.

LIMA, A.M.L.P.; CAVALHEIRO, F.; NUCCI, J.C.; SOUZA, M.A.L.B.; FIALHO, N.O.; DEL PICCHIA, P.C.D. Problemas de utilização na conceituação de termos como espaços livres, áreas verdes e correlatos. In: CONGRESSO BRASILEIRO DE 
ARBORIZAÇÃO URBANA, 2., São Luis, 1994. Anais. São Luis: SBAU, 1994. p.539-553.

MAIS verde, menos estresse. Revista Pesquisa Fapesp, n.92, p.32, out., 2003.

MARICATO, E. Brasil, cidades: alternativas para a crise urbana. Petrópolis, RJ: Vozes, 2001. 204 p.

MEDEIROS, E.B. O lazer no planejamento urbano. 2.ed. Rio de Janeiro:FGV, 1975. 253 p.

MÜLLER,L.P.C. Lazer e desenvolvimento regional. Santa Cruz do Sul: EDUNISC, 2002,230 p.

NUCCI, J.C. Qualidade ambiental e adensamento: um estudo de planejamento da paisagem do distrito de Santa Cecília. São Paulo, 1996. 229 p. Tese (Doutorado) - Faculdade de Filosofia, Letras e Ciências Humanas, Universidade de São Paulo.

PAIVA, H.N.; GONÇALVES, W. Florestas urbanas: planejamento para a melhoria da qualidade de vida. Viçosa, MG: Aprenda Fácil, 2002. 180 p.

PIRACICABA, Leis, Decretos, etc. Lei $n^{\circ}$ 2.643, de 04 de janeiro de 1985. Disciplina o parcelamento do solo. www.ipplap.com.br (10 Set. 2004).

PIRACICABA. Prefeitura Municipal. Instituto de Pesquisas e Planejamento de Piracicaba. Caderno diagnóstico das áreas públicas destinadas para sistema de lazer $e$ institucional em Piracicaba. Piracicaba, 2004.

PIRACICABA. Prefeitura Municipal. Secretaria Municipal de Desenvolvimento Social. Projeto "acolhimento à criança e ao adolescente em situação de rua". Piracicaba, 2002a (Relatório de atividades). 
PIRACICABA. Prefeitura Municipal. Secretaria Municipal de Desenvolvimento Social. Projeto municipal integrado. Piracicaba, 2002b.

PRESOTTO, A. A necessidade dos espaços livres de construção para uso dos moradores: um exemplo no Município de Ilhabela-SP (compact disc). In: CONGRESSO BRASILEIRO DE ARBORIZAÇÃO URBANA, 5., Goiânia, 2002. Anais. Goiânia: SBAU, 2003.

SANTANA, J.S.S.; CARVALHO FERRIANI, M.G. Violência rima com adolescência. In: Associação Brasileira de Enfermagem. Adolescer: compreender, atuar, acolher. Brasilia: ABEn, 2001, p.95-103.

SANTOS, A. C. V. R. Os locais de cultura, esporte e lazer destinados a juventude e a violência da Região Metropolitana de São Paulo. São Paulo: NEV/USP, 2002. (Relatório final de pesquisa. Projeto CEPID I - Monitoramento de Violações de Direitos Humanos, processo, 02/02132-7).

SCHROEDER, H.; LEWIS, C. Psychological benefits and costs of urban forests. In: NATIONAL URBAN FOREST CONFERENCE, 5., LOS Angeles, California. Proceedings. Los Angeles: S.ed., 1991. p.66-68.

SCHROEDER, H.W. Psycological value of urban trees: measurement, meaning, and imagination. In: NATIONAL URBAN FORESTRY CONFERENCE, 3., Orlando, Florida. Proceedings. Orlando: S.ed., 1987. p.55-60.

SILVA, M. A. Percepção da paisagem e planejamento no distrito da Brasilândia - SP. São Paulo, 2002. 243p. Tese (Doutorado) - Faculdade de Filosofia, Letras e Ciências Humanas, Universidade de São Paulo. 
SILVEIRA, S.V. A relação dos espaços livres públicos de lazer com a violência urbana: o caso do Distrito Federal. Brasília, 2000. 156p. Dissertação (Mestrado) - Faculdade de Arquitetura e Urbanismo, Universidade de Brasília.

SULLIVAN, W.C.; KUO, F.E. Do trees strengthen urban communities, reduce domestic violence? www.urbanforestrysouth.usda.gov/pubs/Tech.bulletin/tb4.

ULRICH, R.S. The role of trees in human well-being and health. In: URBAN FORESTRY CONFERENCE, 4., Saint Louis, MI. Proceedings. Saint Louis: S.ed., 1989. p.15-19.

WAISELFISZ, J.J. Juventude, violência e cidadania: Os jovens de Brasília. São Paulo: Cortez/UNESCO, 1998. 174p.

WAISELFISZ, J.J. Mapa da violência II: Os jovens do Brasil. Rio de Janeiro: UNESCO/Instituto Airton Senna/Ministério da justiça, 2000. 136p. 